\title{
Exceptionally preserved conodont apparatuses with giant elements from the Middle Ordovician Winneshiek Konservat-Lagerstätte, Iowa, USA
}

\author{
Huaibao P. Liu, ${ }^{1}$ Stig M. Bergström, ${ }^{2}$ Brian J. Witzke, ${ }^{3}$ Derek E. G. Briggs, ${ }^{4}$ Robert M. McKay, ${ }^{1}$ \\ and Annalisa Ferretti ${ }^{5}$ \\ ${ }^{1}$ Iowa Geological Survey, IIHR-Hydroscience \& Engineering, University of Iowa, 340 Trowbridge Hall, Iowa City, IA 52242, USA \\ 〈huaibao-liu@uiowa.edu〉; 〈robert-mckay@uiowa.edu〉 \\ ${ }^{2}$ School of Earth Sciences, Division of Earth History, The Ohio State University, 125 S. Oval Mall, Columbus, Ohio 43210, USA \\ $\langle$ bergstrom.1@osu.edu \\ ${ }^{3}$ Department of Earth and Environmental Sciences, University of Iowa, 115 Trowbridge Hall, Iowa City, IA 52242, USA 〈brian-witzke@ uiowa.edu〉 \\ ${ }^{4}$ Department of Geology and Geophysics, and Yale Peabody Museum of Natural History, Yale University, New Haven, CT 06520, USA \\ 〈derek.briggs@yale.edu〉 \\ ${ }^{5}$ Dipartimento di Scienze Chimiche e Geologiche, Università degli Studi di Modena e Reggio Emilia, via Campi 103, I-41125 Modena, Italy \\ 〈ferretti@unimore.it〉
}

\begin{abstract}
Considerable numbers of exceptionally preserved conodont apparatuses with hyaline elements are present in the middle-upper Darriwilian (Middle Ordovician, Whiterockian) Winneshiek Konservat-Lagerstätte in northeastern Iowa. These fossils, which are associated with a restricted biota including other conodonts, occur in fine-grained clastic sediments deposited in a meteorite impact crater. Among these conodont apparatuses, the common ones are identified as Archeognathus primus Cullison, 1938 and Iowagnathus grandis new genus new species. The 6-element apparatus of $A$. primus comprises two pairs of archeognathiform $(\mathrm{P})$ and one pair of coleodiform (S) elements. The 15-element apparatus of $I$. grandis n. gen. n. sp. is somewhat reminiscent of the prioniodinid type and contains ramiform elements of alate (one element) and digyrate, bipennate, or tertiopedate types ( 7 pairs). Both conodont taxa are characterized by giant elements and the preservation of both crowns and basal bodies, the latter not previously reported in Ordovician conodont apparatuses. Comparison of the apparatus size in the Winneshiek specimens with that of the Scottish Carboniferous soft-part-preserved conodont animals suggests that the Iowa animals were significantly larger than the latter. The apparatus of A. primus differs conspicuously from the apparatuses of the prioniodontid Promissum from the Upper Ordovician Soom Shale of South Africa although the apparatus architecture of $I$. grandis n. gen. n. sp. shows some similarity to it. Based on the Winneshiek collections, a new family Iowagnathidae in Conodonta is proposed.
\end{abstract}

\section{Introduction}

The Winneshiek Konservat-Lagerstätte was discovered in 2005 when geologists of the Iowa Geological Survey (IGS) were mapping the geology of the Upper Iowa River basin. During the field investigations, a local stratigraphic unit was recognized in the Decorah area in northeastern Iowa (Fig. 1.1, 1.2). From the name of the county where the unit was found, it was named the Winneshiek Shale (McKay et al., 2011; Wolter et al., 2011). Abundant well-preserved fossils, including some with soft-part preservation, occur in the shale, indicating that it is a new Konservat-Lagerstätte (Liu et al., 2006, 2007, 2009). The fauna, particularly the conodonts, indicates that the age of the Winneshiek Lagerstätte is Middle Ordovician (Darriwilian in terms of global classification, and mid to late Whiterockian in regional US Series terminology).

The Winneshiek fossil fauna includes a variety of new forms, and the invertebrate fossils are dominated by arthropods (Lamsdell et al., 2015a; Nowak et al., 2015; Briggs et al., 2015 [2016]), including the oldest eurypterid Pentacopterus (Lamsdell et al., 2015b). Possible algae and jawless fish also occur in the fauna. However, the conodonts are the most common fossils (including isolated elements and natural assemblages), and account for $51 \%$ of the total number of collected specimens $(\mathrm{N}=5,354)$. Most of the conodont elements from the Winneshiek Shale are hyaline. Their crowns are amber-colored (CAI 1.5-2), indicating minimal thermal maturity. Some elements are found in coprolites or gut contents from carnivores. Of even more interest, the Winneshiek Konservat-Lagerstätte preserves abundant conodont beddingplane assemblages. Although some contain elements of different taxa, repeated occurrences of bedding-plane assemblages with consistent element composition and non-random relative element positions indicate that these are natural assemblages (i.e., apparatuses). Several types of conodont apparatuses have been recognized from the Winneshiek Shale, and here we describe two that exhibit large size, unusual architecture and element composition, and which have not been reported previously. These unique conodont materials from the Winneshiek Shale are important for 

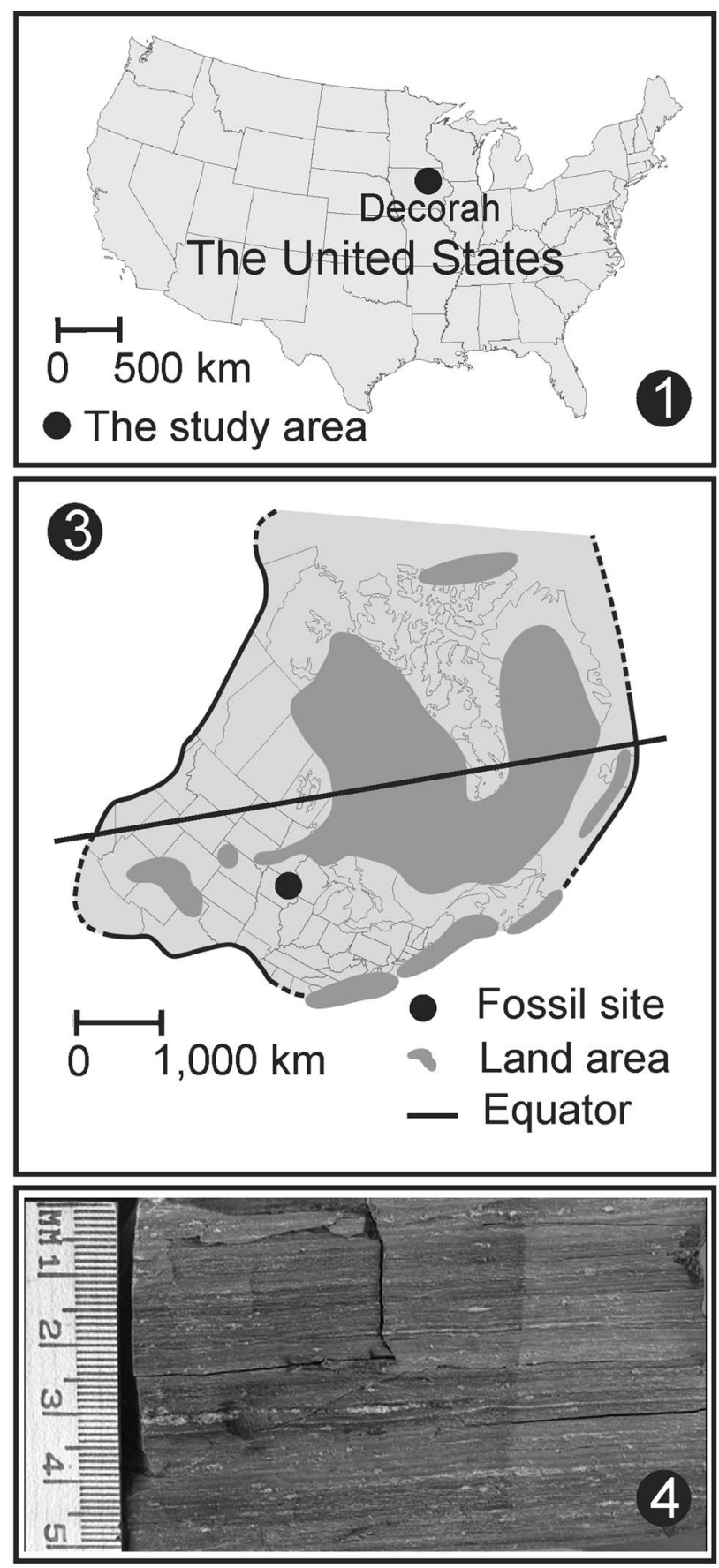

Figure 1. Location of the Winneshiek Konservat-Lagerstätte and the position of the Winneshiek Shale in the Middle Ordovician stratigraphic succession in northeastern Iowa: (1) Map of the United States showing situation of Decorah, Iowa, the study area; (2) The Darriwilian stratigraphic column at Decorah showing principal lithological units; (3) Schematic Middle Ordovician paleogeographic map of most of Laurentia showing the position of the fossil site near the equator and land areas (modified from Witzke, 1990); (4) Polished sample of the Winneshiek Shale showing fine lamination.

their natural classification as well as clarifying evolutionary relationships within the group.

Elements of the Winneshiek conodont apparatuses are usually preserved as three-dimensional mineralized objects in contrast to the elements in most other Ordovician apparatuses, which commonly appear as molds (e.g., Theron et al., 1990; Aldridge et al., 1995, 2013). Furthermore, and unusual for an Ordovician conodont fauna, most of the elements contain basal bodies, which may provide significant value in taxonomic

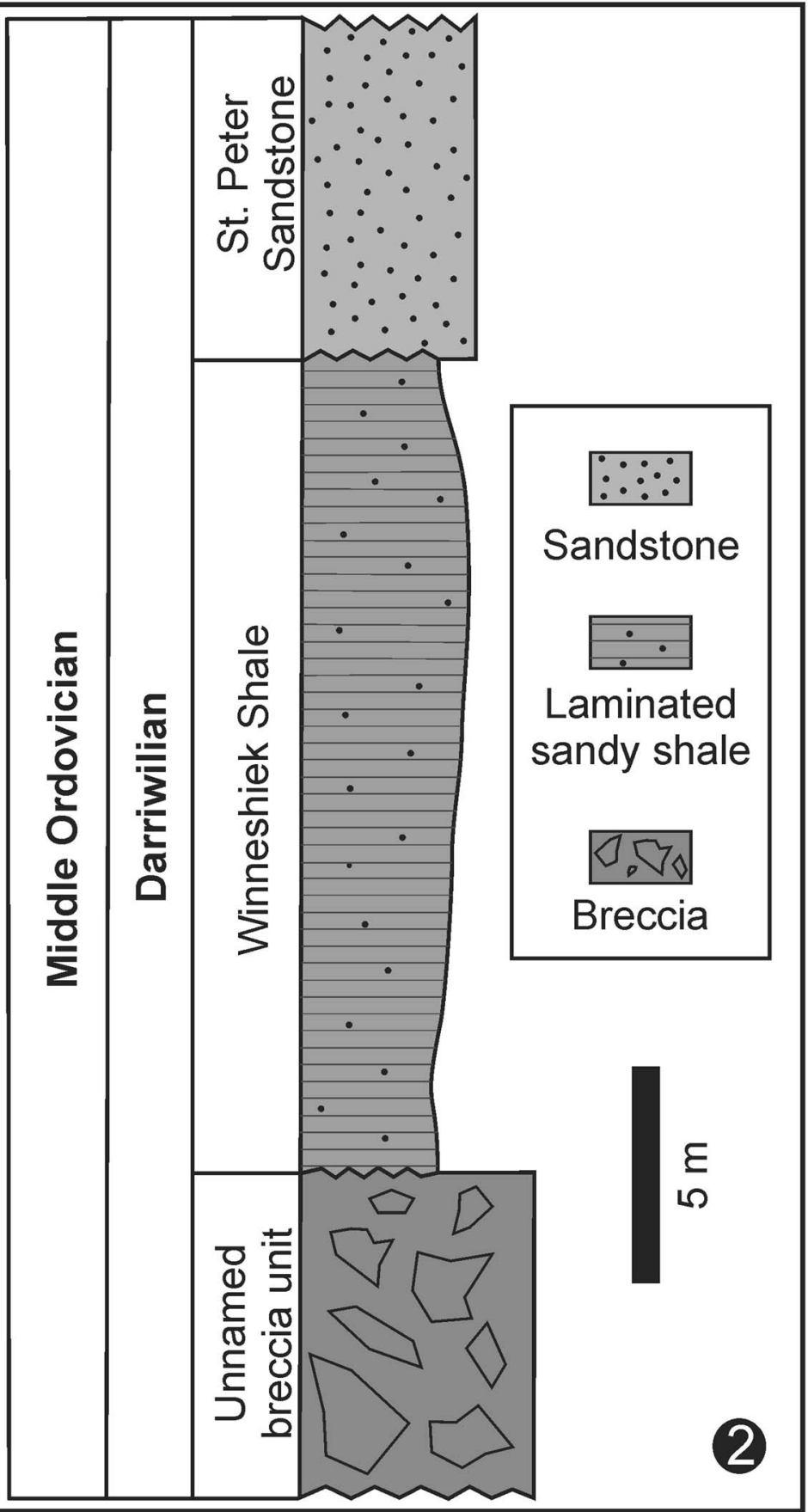

and phylogenetic studies. The apparatuses described below appear to have suffered relatively little postmortem movement of the individual elements: many paired elements are preserved together or in close proximity, some still reflecting the bilateral symmetry, making it possible to hypothesize the spatial arrangement of elements in the apparatus. Because of the three-dimensional preservation of the elements, one side is usually concealed in the shale, but this is not a major problem in conodont identification and apparatus reconstruction 
because different specimens reveal different sides of the elements.

More or less well-preserved Ordovician conodont apparatuses are known from only a handful of localities worldwide (e.g., Aldridge et al., 1995, 2013; Repetski, 1997; Tolmacheva and Purnell, 2002; Stewart and Nicoll, 2003; Dhanda, 2004). Establishing the proper names for the apparatuses from the Winneshiek Lagerstätte based on priority rules is not easy because the form species names used in the literature for some morphologically similar conodont elements are based on fragmentary and/or poorly diagnostic type specimens. The present study focuses on two common types of apparatus in the Winneshiek collections, which we identify as Archeognathus primus Cullison, 1938 and Iowagnathus grandis new genus new species. The complete apparatuses and unusual architectures of both taxa are described herein for the first time.

Both Archeognathus primus and Iowagnathus grandis n. gen. n. sp. from the Winneshiek comprise very large elements with robust basal bodies. The largest element reported herein is longer than $16 \mathrm{~mm}$, thus they are among the largest known (Liu et al., 2011, 2015). Although most apparatuses from the Winneshiek are less than $20 \mathrm{~mm}$ in length, an incomplete apparatus (specimen WS13-1 with 8 elements) of I. grandis n. gen. n. sp. is $>31 \mathrm{~mm}$, and the complete A. primus apparatus shown in Figure 2.1 has a length $>13 \mathrm{~mm}$. Based on the sizes of apparatuses and individual elements, the I. grandis $\mathrm{n}$. gen. n. sp. apparatuses from the Winneshiek Lagerstätte have an estimated average length of $2-3 \mathrm{~cm}$, which is larger than the Upper Ordovician apparatuses described from the Soom Shale in South Africa (e.g., Theron et al., 1990; Aldridge et al., 2013). Although individual elements from both locations may be of comparable size (up to $15-20 \mathrm{~mm}$ ), the Winneshiek Shale elements are notably more robust. Based on the conodont anatomy illustrated by the soft-bodied Carboniferous specimens from Scotland, several studies tried to estimate conodont body size from their apparatuses and elements (e.g., Purnell, 1994, 1995). The length of the body of the conodont animals from the Carboniferous of Scotland (Aldridge et al., 1986, 1993) is about 20 times that of the apparatus. Extrapolating this relationship to the Winneshiek specimens suggests that the Iowa conodont animals may have reached lengths of $>0.5 \mathrm{~m}$, especially for Iowagnathus grandis.

\section{Geological setting of the Winneshiek Shale}

The Winneshiek Shale, which hosts the Winneshiek KonservatLagerstätte, is a greenish-brown to dark-gray, laminated sandy shale unit (Fig. 1.4), with some layers containing abundant pyrite and a high content of carbonaceous material. It is disconformably overlain by the St. Peter Sandstone, which is widely distributed in the Upper Mississippi Valley, and overlies a local un-named, thick and massive impact breccia unit (Fig. 1.2). In the study area, most of the Winneshiek Shale is buried in its $\sim 25 \mathrm{~km}^{2}$ distribution area. The only known exposure of the unit is a small section at Decorah, Iowa that is mostly submerged in the Upper Iowa River. This exposure was excavated during the summer of 2010 by temporarily damming the river and using earth-moving equipment to dig into the riverbed, exposing a total thickness of $\sim 4 \mathrm{~m}$ of the upper
Winneshiek Shale. This $4 \mathrm{~m}$ section was sampled in detail and more than 2.5 tons of shale were systematically collected from it. This material was stored in the IGS facility building on the Oakdale Research Park Campus of the University of Iowa and kept in water until the shale slabs were split in the laboratory and carefully searched for fossils under binocular microscopes. With the assistance of trained students, this search was completed in three years, and resulted in a collection of more than 5,000 fossil specimens.

The full thickness of the Winneshiek Shale was revealed in two cores, which were drilled for the investigation of the Winneshiek Konservat-Lagerstätte. One of these is located at the single outcrop and the other is in the downtown area of the city of Decorah, $\sim 3.5 \mathrm{~km}$ distant. The complete Ordovician sedimentary succession in the Decorah region was obtained from local geological data and from investigations of wells, some of which penetrated the Cambrian. Based on rock chips, the Winneshiek Shale has been recognized in at least 24 wells, indicating that the unit is $17-27 \mathrm{~m}$ thick and is distributed across the impact basin (Liu et al., 2009; McKay et al., 2011; Wolter et al., 2011). Conodonts and other fossils occur through the Winneshiek Shale succession, but most of the fossils dealt with here were collected from the upper four meters of the excavated section.

\section{Age of the Winneshiek Shale}

Among the fossils collected from the Winneshiek Shale, only the conodonts currently furnish useful biostratigraphic evidence. However, pending assessment of the entire conodont fauna, our present focus is on the age indications provided by the two multielement species described herein along with one other species, Multioistodus subdentatus. None of these is a zone index, but their distribution elsewhere gives some indication of the age of the Winneshiek Shale.

The P (archeognathiform) elements of Archeognathus primus were first described from the Dutchtown Formation of Missouri (Cullison, 1938). Branson (1944, pls. 8, 9) published additional illustrations of Dutchtown conodont species, but provided no descriptions. Youngquist and Cullison (1946) gave a more extensive account of this conodont fauna, but did not include any information about $A$. primus, presumably because they believed that it was not a conodont. Based mainly on new Dutchtown specimens, Klapper and Bergström (1984) described the "jaw-like" specimens of A. primus in considerable detail and recognized their conodont nature, but their study specimens did not permit any reconstruction of the apparatus. They recognized the similarity between the Dutchtown archeognathiform (P) and coleodiform (S) elements and "considered the possibility that they were elements of the same apparatus", noting that "confirmation of this idea, however, requires additional evidence" (Klapper and Bergström, 1984, p. 974). The present paper provides this evidence.

The Dutchtown Formation crops out to a limited extent in southern and southeastern Missouri, where it rests unconformably on the St. Peter Sandstone and is overlain by the Joachim Dolomite (see Branson, 1944, fig. 12). Hence, it differs from the Winneshiek Shale in lying above rather than below the St. Peter Sandstone, although many authors have suggested that the 

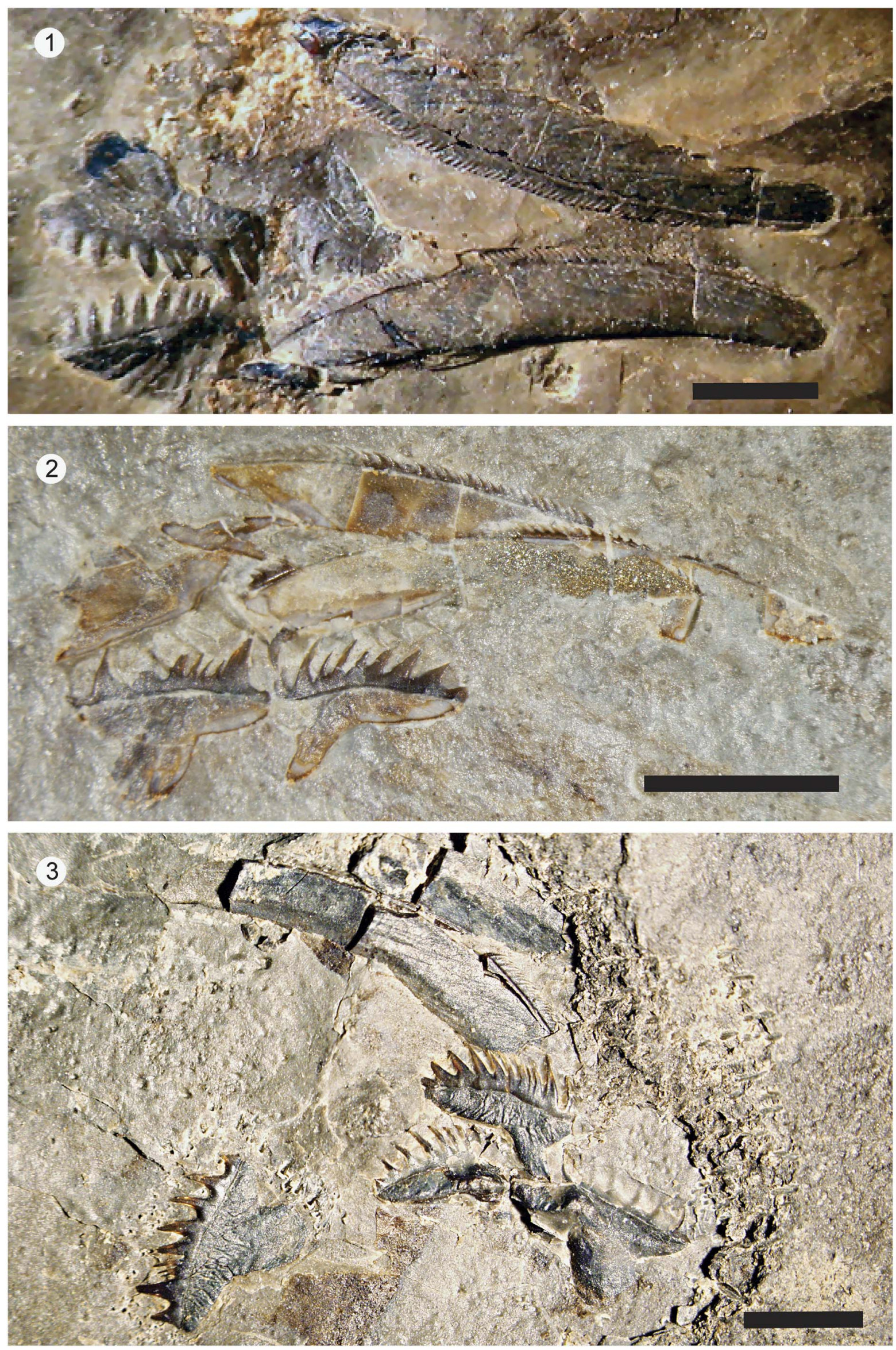
St. Peter Sandstone is not the same age everywhere in the Midcontinent region (e.g., Ross et al., 1982). It should also be noted that regional subsurface studies suggest that the St. Peter Sandstone interfingers with the calcareous Dutchtown Formation (e.g., Rexroad et al., 1982, fig. 2; Witzke and Metzger, 2005). No archeognathiform elements have been reported from the Joachim Dolomite (Branson and Mehl, 1933; Andrews, 1967) or younger strata in Missouri.

Among the Dutchtown conodonts, Phragmodus flexuosus and $P$. polonicus are biostratigraphically important. The former is a geographically widespread species in upper Darriwilian and lower Sandbian strata in North America. The latter species, which has been collected from the type locality of the formation by one of us (SMB), is characteristic of the middle-upper Darriwilian of North America and occurs in coeval strata in Baltoscandia, Poland, and Siberia (see Ethington and Clark, 1981 and Dzik, 1994 for discussions of the taxonomy and other aspects of this species). The Siberian Platform occurrences (Moskalenko, 1970, 1973, 1983) in the Vihorevian Stage are of special interest because, as recognized by Moskalenko (1970), the conodont fauna of this stage is similar to that of the Dutchtown Formation. The Siberian fauna includes, among other taxa, archeognathiform elements that may be congeneric with Archeognathus and one element (see synonymy in the Systematic section) that resembles the $\mathrm{P}_{2}$ element of Iowagnathus n. gen. of the Winneshiek fauna. Moskalenko described all her material only as form taxa and they have not yet been revised in modern multielement taxonomy. Moskalenko (1983) correlated her Vihorevian fauna with that of the Darriwilian Eoplacognathus suecicus Zone in Baltoscandia. This might be correct although the absence of biostratigraphically important Baltoscandian taxa in the Siberian fauna makes precise correlation difficult.

In the Winneshiek conodont fauna, Multioistodus subdentatus, a species originally described from the Dutchtown Formation (Cullison, 1938), has been identified. This species has been recorded from the lower part of the Simpson Group of the Arbuckle Mountains of Oklahoma (e.g., Bauer, 2010), the Burger and Tyner formations of northeastern Oklahoma (Bauer, 1989), and several formations in Utah and Nevada (Ethington and Clark, 1981). All currently known occurrences of this species are of Darriwilian age.

Because of their successional relationship, the biostratigraphic age of the overlying St. Peter Sandstone would provide a minimum age for the Winneshiek Shale. Although the St. Peter Sandstone is essentially unfossiliferous, shaly intervals, particularly in the lower part of the unit, have yielded some biostratigraphically significant conodonts in drillcores from Iowa and Minnesota (Witzke and Metzger, 2005). The most diagnostic fauna, which is from the Camp Quest core of Lemars, Plymouth County, in northwestern Iowa, includes representatives of Phragmodus flexuosus, Leptochirognathus sp., Erraticodon sp., Cahabagnathus sp. cf. C. friendsvillensis, Archeognathus sp., and Eoplacognathus sp., indicating a late
Darriwilian age. This age is consistent with the resemblance of this conodont fauna to that of the McLish Formation of Oklahoma (Bauer, 1987). The St. Peter Sandstone in southwestern-most Indiana (i.e., even farther afield than northwest Iowa) has also yielded a somewhat similar, but taxonomically less diverse, conodont fauna (Rexroad et al., 1982). A taxonomically unusual, but probably approximately coeval, conodont fauna occurs in strata identified as the Dutchtown Formation in southeastern Indiana (Ethington et al., 1986). All the data indicate that conodont faunas with archeognathiform elements were widely distributed in the Midwest in the late Darriwilian. In view of the fact that the Winneshiek Shale is older than at least part of the St. Peter Sandstone, its fauna is also likely to be older. However, the geographically widespread Histiodella-Paraprioniodus-Pteracontiodus-Fahraeusodus fauna of early Darriwilian age is absent from both the Dutchtown and Winneshiek formations, which suggests that the Winneshiek Shale is of middle-late Darriwilian age. This is consistent with the fact that the early Darriwilian fauna occurs in the upper Everton Formation, which underlies the St. Peter Sandstone, in Missouri and Arkansas.

\section{Paleoecology and taphonomy of the Winneshiek fauna}

Paleogeographic studies indicate that northeastern Iowa occupied a marginal to near-shore setting in the tropical zone of Laurentia during the Middle Ordovician (Fig. 1.3) (Witzke, 1990; Niocaill et al., 1997; Jin et al., 2013). Recent analyses of subsurface data indicate that the Winneshiek Shale and the underlying breccia unit are confined to a circular basin with a diameter of $5.6 \mathrm{~km}$ in the Decorah area. Multiple lines of geological evidence indicate that this circular basin was formed by a meteorite impact (Liu et al., 2009; McKay et al., 2011). The shape and dimension of the crater have recently been established by aerial geophysical surveys conducted by the U.S. Geological Survey (Koontz and McKay, 2013), and the crater has been named the Decorah Impact Structure. The crater resulted in an enclosed basin where anoxic conditions developed in the relatively undisturbed bottom water, which provided appropriate taphonomic conditions for the exceptional preservation that characterizes the Winneshiek Konservat-Lagerstätte.

Although the deposit is marine influenced, many typical Ordovician open-marine fossils, such as trilobites, graptolites, corals, bryozoans, and echinoderms, are absent in the Winneshiek fauna, which includes eurypterids (Lamsdell et al., 2015b), phyllocarids (Briggs et al., 2015 [2016]), ostracodes, jawless fish, and linguloids. The Winneshiek Shale also yields abundant bromalites (mineralized gut contents and coprolites) and algae. The unusual composition of the fauna suggests that it inhabited a restricted environment, likely in brackish water, with a low salinity that was inhospitable to typical marine taxa (Liu et al., 2006, 2007, 2009; Witzke et al., 2011).

Figure 2. Three bedding-plane conodont apparatuses of Archeognathus primus Cullison, 1938 from the Winneshiek Shale. Note that all these 6-element apparatuses, which we interpret as complete, contain only one pair of coleodiform $\mathrm{S}$ elements and two pairs of ramiform $\mathrm{P}$ elements $\left(\mathrm{P}_{1}\right.$ and $\left.\mathrm{P}_{2}\right)$, all with large basal bodies. Also note that the elements are consistently arranged, from left to right in Figure 2.1 and 2.2 , as paired $\mathrm{P}_{1}$, $\mathrm{P}_{2}$, and $\mathrm{S}$ : $(\mathbf{1}) \mathrm{SUI} 102853$; $(\mathbf{2}) \mathrm{SUI}$ 139882 (WL143); (3) SUI 139883 (WS16-1). Scale bar = $2 \mathrm{~mm}$. 


\section{Materials and methods}

Among the 5,354 numbered specimens collected from the Winneshiek Shale, 2,749 are conodonts and more than $10 \%$ of these conodont specimens are bedding-plane assemblages. As mentioned above, this study focuses on the apparatuses of two taxa identified as Archeognathus Cullison and a new genus Iowagnathus. Each taxon is represented by multiple, apparently complete or nearly complete apparatuses.

Based on their position in the section, the specimens collected from the top to the base of the excavated section are labeled WS1 through WS18, each number representing a stratum thickness of about $20 \mathrm{~cm}$. Other specimens were collected from random slabs that were washed out from the river bed during flooding. These specimens are labeled WL.

Repository and institutional abbreviation.-The specimens described and illustrated herein are reposited in the Paleontology Repository of the Department of Earth and Environmental Sciences, the University of Iowa, and are labeled SUI.

\section{Systematic paleontology}

Conodonta Eichenberg, 1930

Family Archeognathidae Miller, 1969

Diagnosis.-Large conodonts with individual elements that can be longer than $10 \mathrm{~mm}$; a highly modified apparatus consisting of only three pairs of elements, one pair of coleodiform and two pairs of archeognathiform; all elements containing robust basal bodies with distinctive radial or oblique ridge-and-groove surface ornamentation; denticles hyaline and fibrous, with rare or absent white matter.

Remarks.-Representatives of this family are currently known only from the Darriwilian to Sandbian interval of the Ordovician. There is only one referred genus: Archeognathus Cullison, 1938. Pending revision of relevant taxa (see Klapper and Bergström, 1984; Miller, 1969; Sweet, 1988), we assign Archeognathus to Archeognathidae Miller, 1969, following Klapper and Bergström (1984).

Genus Archeognathus Cullison, 1938

Type species.-Archeognathus primus Cullison, 1938, by original designation.

Diagnosis.-Complete apparatus consisting of three pairs of large elements. One pair of coleodiform (S) elements long and elongate; thick basal body slightly curved with numerous small denticles along the upper (convex) margin to form a saw-blade shape. Two other pairs of archeognathiform elements $\left(\mathrm{P}_{1}\right.$ and $\mathrm{P}_{2}$ ) smaller, with fewer but much more robust denticles, none developed as a cusp; prominent basal bodies of $\mathrm{P}_{1}$ and $\mathrm{P}_{2}$ elements with conspicuous handle-like projection from a more or less straight lower margin.
Remarks.-In all important morphological features, including the appearance of the basal body, the $\mathrm{P}$ elements of this apparatus are identical with the holotype of $A$. primus from the Dutchtown Formation (Cullison, 1938, pl. 29, figs. 10a, b). However, in accordance with taxonomic priority rules, it is necessary to assess whether any other element in the Archeognathus apparatus was assigned to a new genus prior to 1938. The fact that this apparatus contains only one other type of paired element, here referred to as the $\mathrm{S}$ element, would appear to make it an easy task to establish priority. In previous conodont faunal studies, blade-like specimens of similar appearance to the $\mathrm{S}$ element in the Winneshiek taxon have in most cases been referred to the form genus Coleodus Branson and Mehl, 1933. Unfortunately, as noted by Klapper and Bergström (1984), Branson and Mehl's (1933) cotypes of $C$. simplex, the type species of Coleodus, which were collected from the Harding Sandstone of Colorado, are too fragmentary to permit a full description and confident identification, and it has never been revised in terms of multielement taxonomy. Inspection of Branson and Mehl's (1933, pl. 1, fig. 22) illustration of the most complete specimen, which we here select as the lectotype of $C$. simplex, shows that its denticulation and the shape of both the lower margin and lateral face of the process differ markedly from the corresponding features in the coleodiform element ( $\mathrm{S}$ element) of A. primus. Thus, it is unlikely that they represent the same species. In addition, the Harding Sandstone is of late Sandbian age and substantially younger than both the Dutchtown and Winneshiek formations.

Coleodus has been used as a genus designation for several Middle, and even Late, Ordovician taxa of both hyaline and albid types of conodonts based on a superficial general similarity to $C$. simplex in descriptions of North American, Baltoscandic, and Chinese faunas that completely lack archeognathiform elements (e.g., Moskalenko, 1970; An et al., 1983; Bauer, 2010). This suggests that Coleodus has become a wastebasket genus for homeomorphic but not closely related conodont elements, and that these species are not congeneric with A. primus. Thus, although Coleodus was established a few years earlier, we use Archeognathus as the generic designation for our Winneshiek taxon. Winneshiek apparatuses of this taxon include elements clearly representing Youngquistina Miller, 1969 and this genus is here regarded as a junior synonym of Archeognathus.

Neocoleodus spicatus Branson and Mehl, 1933, the type species of Neocoleodus, has been recorded from several formations but is currently poorly known. It may be related to Archeognathus at the family level, but this type of element is not present in our Winneshiek collections.

\section{Archeognathus primus Cullison, 1938}

Figures 2-4, 8.1-8.6, 9.1

1938 Archeognathus primus Cullison, p. 227, pl. 29, figs. $16 \mathrm{a}, \mathrm{b}$.

1969 Youngquistina mitteni Miller, p. 505, fig. 1.

1984 Archeognathus primus Cullison, 1938; Klapper and Bergström, p. 954, figs. 3-8, 9A, B, 10 (includes further synonyms). 


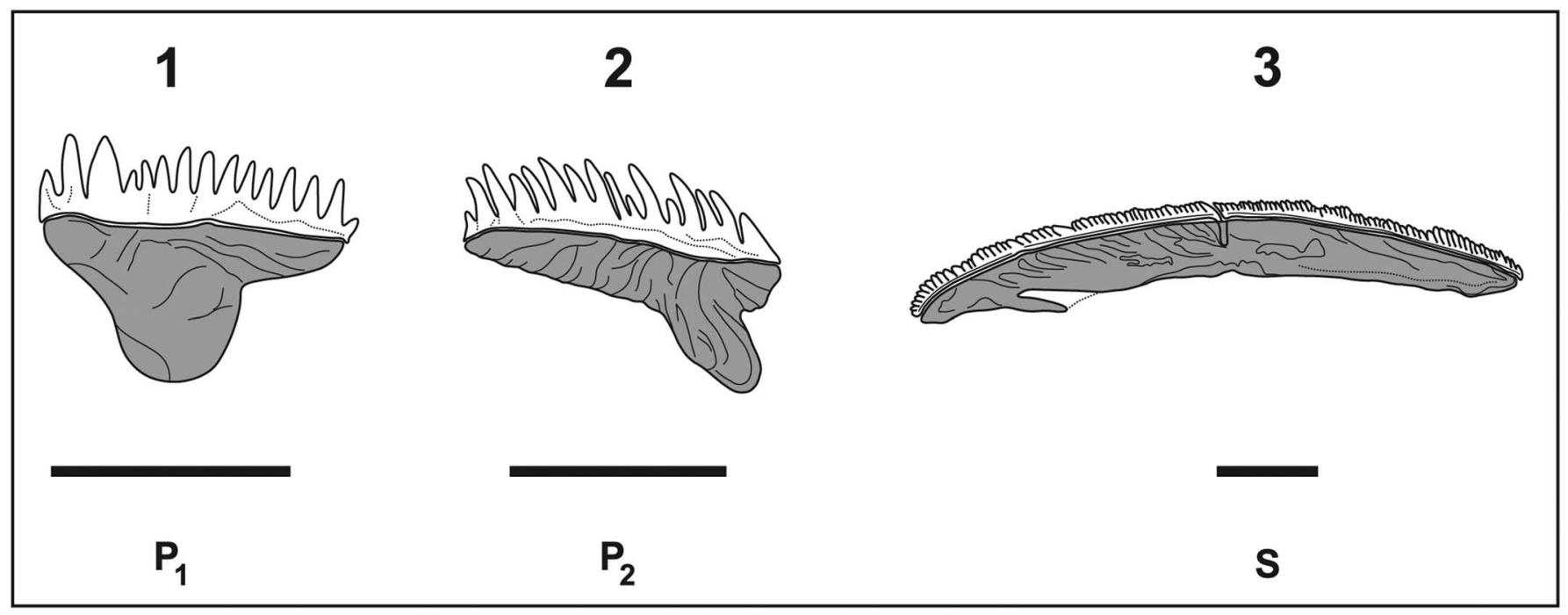

Figure 3. Camera-lucida drawings of the three types of elements in the Archeognathus primus apparatus: (1) $\mathrm{P}_{1}$ element, SUI 139884 (WS14-522); (2) $\mathrm{P}_{2}$ element, SUI 139885 (WS12-382); (3) S element, SUI 139886 (WL13). Scale bar $=2 \mathrm{~mm}$.

Material.-Complete or nearly complete apparatuses: SUI 102853, WL143, WL238, WL240, WL281, WS16-1, WS17-34; incomplete apparatuses: WL70, WL213, WL227, WL229, WL256, WL277, WS10-48, WS10-61, WS12-199, WS13-589, WS15-342, WS16-540; individual elements: WL13, WL58, WL211, WL225, WS12-251, WS12-382, WS14-522, WS16-386.

Diagnosis.-The same as for the genus above.

Occurrence.-Darriwilian to Sandbian (Middle to Upper Ordovician) of North America and possibly the Siberian Platform.

Description.-Representatives of Archeognathus primus are some of the most common conodonts in the Winneshiek fauna and they are preserved both as individual elements and as apparatuses. A complete apparatus of this taxon (Figs. 2.1-2.3, $4,9.1$ ) includes six elements in three pairs, one of coleodiform and two of archeognathiform elements, all of them with robust basal bodies. The elements in each pair appear to be mirror images of each other, reflecting a bilateral symmetry. Locations of the three paired elements are consistent in its apparatus as shown by Figure 2.1 and 2.2 and illustrated by Figure 4 .

The complete apparatuses of A. primus from the Winneshiek Shale are the first of this taxon discovered anywhere in the world. Because the element morphology and architecture of the apparatus differ greatly from those previously described from the Ordovician, applying the location system of Sweet (1988; also see Purnell et al., 2000), which is now commonly used in conodont multielement classification, is not straightforward. In the collections at hand, we have failed to find any typical $\mathrm{M}$ elements in this type of apparatus. The absence of such an element is not a unique feature and has been reported in a variety of Ordovician multielement taxa, as well as in taxa of other ages.

Although several complete apparatuses of A. primus occur in our collection, it is still a challenge to recognize the orientation of the apparatus in the animal without evidence of the soft parts. However, the general location of these pairs of elements is consistent in these apparatuses. For descriptive purposes, we use conventional terminology. Based on their position at one end of the apparatus, as well as their multidenticulated morphology, it is likely that the single pair of coleodiform elements in the A. primus apparatus represents a highly modified S element. On this basis, the two pairs of archeognathiform elements can be designated $\mathrm{P}$ elements and are here referred to as $\mathrm{P}_{1}(\mathrm{~Pa})$ and $\mathrm{P}_{2}(\mathrm{~Pb})$ elements (Figs. 3, 4) occupying a caudal position according to the scheme of anatomical notation by Purnell et al., (2000).

The coleodiform $\mathrm{S}$ element of $A$. primus resembles a slightly curved and elongated saw blade and can reach a length of $>10 \mathrm{~mm}$ in the Winneshiek specimens. The degree of curvature of this element varies (Figs. 2.1, 2.2, 3.3, 8.4). Numerous, short, slightly reclined in the same direction, and densely packed (8-10 per $\mathrm{mm}$ ) denticles form a uniform row along the convex margin. No cusp is present in either the left or right representatives of this pair of elements. The basal groove has a robust and thick basal body. In some specimens, an earlike projection (indicated by the red arrow in Fig. 8.4) occurs near the posterior end of the concave side of the basal body of the element. This type of element is always the largest one in its apparatus (the example illustrated in Fig. 3.3 is $12.5 \mathrm{~mm}$ long).

The archeognathiform $\mathrm{P}_{1}$ and $\mathrm{P}_{2}$ elements in the apparatus of A. primus are smaller than the $\mathrm{S}$ element and are typically 2-3 mm long. Klapper and Bergström (1984), however, recorded specimens of this element 5-7 mm long and noted that they had seen specimens twice as large. Because they described the morphology of these elements in considerable detail, we restrict our description here to a few details. The $\mathrm{P}_{1}$ and $\mathrm{P}_{2}$ elements usually have $10-16$ prominent, somewhat cone-shaped, denticles. Costae may occur on some denticle surfaces. These denticles are well separated and arranged in a row along the margin of the crown of the element. They are much longer and thicker than those in the $\mathrm{S}$ element with a length of $\sim 0.5 \mathrm{~mm}$ that may vary along the denticle row. In many specimens, slightly shorter denticles occur between the larger ones, but none is developed as a distinct cusp. In several apparatus specimens, the denticles of the $\mathrm{P}$ elements point in the 


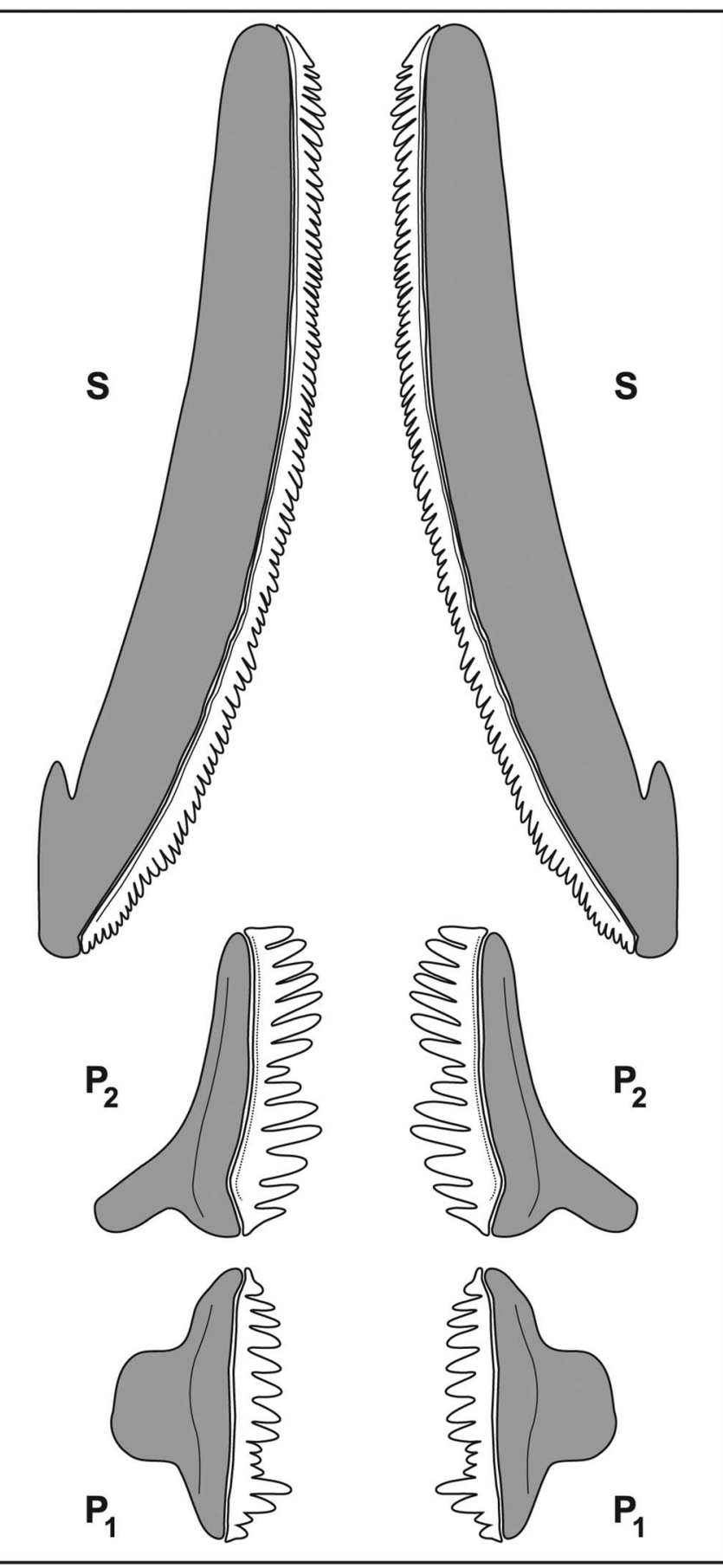

Figure 4. Schematic illustration of the architecture of the 6-element Archeognathus primus apparatus.

opposite direction to those in the $\mathrm{S}$ elements (Fig. 2.1, 2.2). Because this difference in denticle direction often occurs in our Archeognathus apparatuses, it may reflect the position of the elements in the living animal. In most specimens, the denticles of the $\mathrm{P}_{1}$ element are straighter than those in the $\mathrm{P}_{2}$ element. The space between adjacent denticles may vary slightly in the archeognathiform $\mathrm{P}_{1}$ and $\mathrm{P}_{2}$ elements, but their bases are connected by a continuous lamina. Longitudinal striae, which were described by Cullison (1938, p. 227) and later illustrated by Miller et al., (1947, pl. 1), are not evident in our specimens.
Both the $\mathrm{P}_{1}$ and $\mathrm{P}_{2}$ elements are provided with very prominent basal bodies. The most conspicuous feature of these bodies is what Klapper and Bergström (1984) referred to as a downward projection, oriented more or less obliquely to the denticle row. Based on the shape, we refer to this structure as a "handle-like" base projection. This projection is broader and located in a more central position in the $\mathrm{P}_{1}$ element than that in the $\mathrm{P}_{2}$ element (Figs. 2, 3.1, 3.2, 4, 8.1-8.3). In all the three pairs of elements of the A. primus apparatus, ridge-and-groove ornaments commonly occur on the surface of the basal bodies (Figs. 2.1, 2.3, 8.1-8.3). Where preserved, they are obliquely arranged on the $\mathrm{S}$ elements and roughly radiate from the base projection in the $\mathrm{P}_{1}$ and $\mathrm{P}_{2}$ elements.

Remarks.-The holotype of Youngquistina mitteni Miller, 1969, the type species of Youngquistina, which was collected from the Harding Sandstone in Colorado, agrees in all significant morphological features with the $\mathrm{P}_{1}$ element of A. primus and we consider Youngquistina to be a junior synonym of Archeognathus. The unidentified specimen with prominent basal body described by Mosher and Bodenstein (1969) from the lower part of the Chickamauga Limestone of Alabama is clearly a P element of an archeognathid. With a total size of $\sim 1 \mathrm{~mm}$ long, this Chickamauga specimen is less than half the size of many Winneshiek examples of this element.

Although coleodiform elements are widespread in Middle and early Late Ordovician faunas, this is the first report of a natural apparatus in which they are associated with archeognathiform elements. However, some possible co-occurrences of coleodiform and archeognathiform elements have been reported from other Ordovician strata, such as in the conodont faunas of the St. Peter Sandstone of Iowa (Witzke and Metzger, 2005). Webers (1966) reported Neocoleodus spicatus and Coleodus simplex (Webers, 1966, pls. 4.5, 5.11; also cf. elements identified as species of Lonchodus illustrated by Stauffer, 1935, pl. 10, figs. 1-7, 9-12) from the Glenwood Formation of Minnesota, which may represent elements of a species of Archeognathus. Mound (1965, pl. 4) reported Polycaulodus reversus and Pravognathus idoneus from the Joins Formation of Oklahoma, which possibly also represent a species of Archeognathus. Klapper and Bergström (1984) discussed other records of possible archeognathiform specimens from North America and Siberia. Because we have not had the opportunity to reexamine these taxa, we cannot add further information but note that the specimens illustrated by Moskalenko (1983, figs. 3L, N, but not M) as Neocoleodus dutchtownensis Youngquist and Cullison show some similarity to archeognathiform elements. These and other co-occurrences of coleodiform and archeognathiform elements suggest that there were additional Ordovician archeognathid taxa, but far more extensive collecting is needed to confirm this observation.

Coleodiform elements have been recorded as species of Coleodus or Loxodus from a variety of formations in North America, Baltoscandia, Siberia, and China, where they are not associated with archeognathiform elements. Three examples of this are records of a species of Coleodus from the Winnipeg Formation of South Dakota (Sweet, 1982), the Mystic Formation of Quebec (Barnes and Poplawski, 1973), and the Hølonda Limestone of the Norwegian Caledonides (Bergström, 1980). 
In many cases, these elements are not hyaline, have somewhat larger denticles, and a carminate rather than bowed blade with a more pointed posterior blade end. An example of this type of albid element is Loxodus dissectus An in An et al., 1983 from the Machiagou Formation in northern China (An et al., 1983, text-figs. 5, 7, 13; Wang et al., 2014, pl. 3, fig. 8). This species is relatively common in this formation and used as a zonal index, but is not associated with archeognathiform elements. It should also be noted that incomplete specimens of the blade-like albid elements of, for example, Appalachignathus Bergström et al., 1974 and Loxodus Furnish, 1938, and the M element of Bergstroemognathus extensus (Graves and Ellison, 1941), could be confused with the S element of Archeognathus primus. Hence, care must be exercised in the identification of coleodiform elements because this type of element is homeomorphic and probably a component of a variety of multielement taxa.

\section{Family Iowagnathidae new family}

Diagnosis.—Large conodonts with individual elements up to $16 \mathrm{~mm}$ or more in length; complete apparatus with 15 elements somewhat reminiscent of the prioniodinid type; elements with two or three multidenticulated processes and a distinct cusp; denticles hyaline and fibrous, with rare or absent white matter, but without obvious cavity; basal bodies robust, surface with radial ridge-and-groove ornamentation.

Remarks.-Representatives of this family are known only from the Middle Ordovician. Only one referred genus: Iowagnathus new genus.

\section{Genus Iowagnathus new genus}

Type species.—Iowagnathus grandis new species.

Etymology.-Named for the State of Iowa, the source of the material.

Diagnosis.—Same as for species by monotypy.

Remarks.-Iowagnathus $\mathrm{n}$. gen. is strikingly different from Archeognathus and others in the element component and arrangement of the apparatus, as well as in the morphology of the individual elements (Figs. 5-7, 8.7-8.19, 9.2), suggesting no close affinity at the genus level. In the presence of a denticulated anterior process in some of its elements, Iowagnathus n. gen. is reminiscent of the Darriwilian hyaline genus Paraprioniodus Ethington and Clark, 1981, especially as represented by its type species $P$. costatus (Mound) (see Ethington and Clark, 1981, p. 77-79; Rexroad et al., 1982, p. 9; Bauer, 2010, p. 16-17). However, as shown by the reconstructions of the $P$. costatus apparatus by those authors, the significant differences in the morphology of particularly the $\mathrm{S}_{0}, \mathrm{M}$, and some $\mathrm{S}$ elements of the type species of Iowagnathus n. gen. and Paraprioniodus support separation at the genus level. The elements of Iowagnathus $\mathrm{n}$. gen. also exhibit some general similarity to those of the hyaline genus Erismodus Branson and Mehl, 1933. However, as illustrated by Sweet (1988), the elements of Erismodus lack the long denticulated anterior process in corresponding elements of Iowagnathus n. gen., and the appearance of the $S_{0}$ element is completely different between the two taxa (for further discussion of Erismodus, see Sweet, 1982, p. 1039-1040). Based on the available information, we regard Iowagnathus n. gen. and Erismodus as separate genera. Another genus exhibiting some superficial similarity to Iowagnathus is Erraticodon Dzik, 1978. However, there are significant differences between especially the S and P elements of Erraticodon and those of Iowagnathus n. gen., and these genera are not synonymous.

\section{Iowagnathus grandis new species}

Figures 5-7, 8.7-8.19, 9.2

?1970 Microcoelodus festivus sp. nov. Moskalenko, p. 72, pl. 1, fig. 8 .

Type specimens.-Holotype: apparatus specimen SUI 139888 (WS18-266) (Fig. 5.2); Paratype: apparatus specimen SUI 139887 (WS18-60) (Fig. 5.1). Both are from the Winneshiek Shale, northeast Iowa.

Material.-Complete or nearly complete apparatuses: SUI 102852, WL151, WS10-347, WS17-273, WS17-275, WS18-79, WS18-246; incomplete apparatuses: WL26, WL60, WL89, WL152, WL156, WL173, WL179, WS10-72, WS10-195, WS10-197, WS11-21, WS13-1, WS13-656, WS15-71, WS16-82, WS17-2, WS17-287; individual elements: WL208, WS11-342, WS13-587, WS14-553, WS15-342, WS16-80, WS16-235, WS17-296, WS18-265.

Etymology.-Grandis (Latin), big, referring to the large size reached by the elements and apparatus.

Diagnosis.- Hyaline conodonts with an apparatus comprising 15 large ramiform elements, fourteen $\left(\mathrm{P}_{1}, \mathrm{P}_{2}, \mathrm{M}, \mathrm{S}_{1-4}\right)$ in pairs and one $\left(S_{0}\right)$ unpaired (Figs. 5, 6, 9.2). The unpaired $S_{0}$ element symmetrical and morphologically jaw-like, essentially alate and without posterior or anterior process; cusp short and not prominent. The 14 paired elements more or less digyrate, multidenticulated, with two or three denticulated processes, near symmetrical to asymmetrical; each of the paired elements with a well-developed cusp. Denticles peg-like, sharply pointed, essentially rounded in cross section, and more or less reclined. All elements possess prominent basal bodies and grooves but without cavities.

Occurrence.-Darriwilian (Middle Ordovician, Whiterockian), North America and possibly coeval strata in Siberia.

Description.-Iowagnathus grandis n. gen. n. sp. is one of the most abundant conodont taxa in the Winneshiek collection. The apparatus of this species is composed of 15 large ramiform elements with robust basal bodies, 14 of which are paired and more or less symmetrical to asymmetrical, and one unpaired and essentially symmetrical. The unpaired element (indicated by arrows in Fig. 5.1, 5.2) is referred to as the $S_{0}$ element. Four pairs of mutually similar $S$ elements form a modified symmetry transition series that includes $S_{1}, S_{2}, S_{3}$, and $S_{4}$ elements. The apparatus also has paired $\mathrm{M}, \mathrm{P}_{1}$, and $\mathrm{P}_{2}$ elements. Complete apparatuses of this taxon are illustrated in Figure 5.1 and 5.2, 

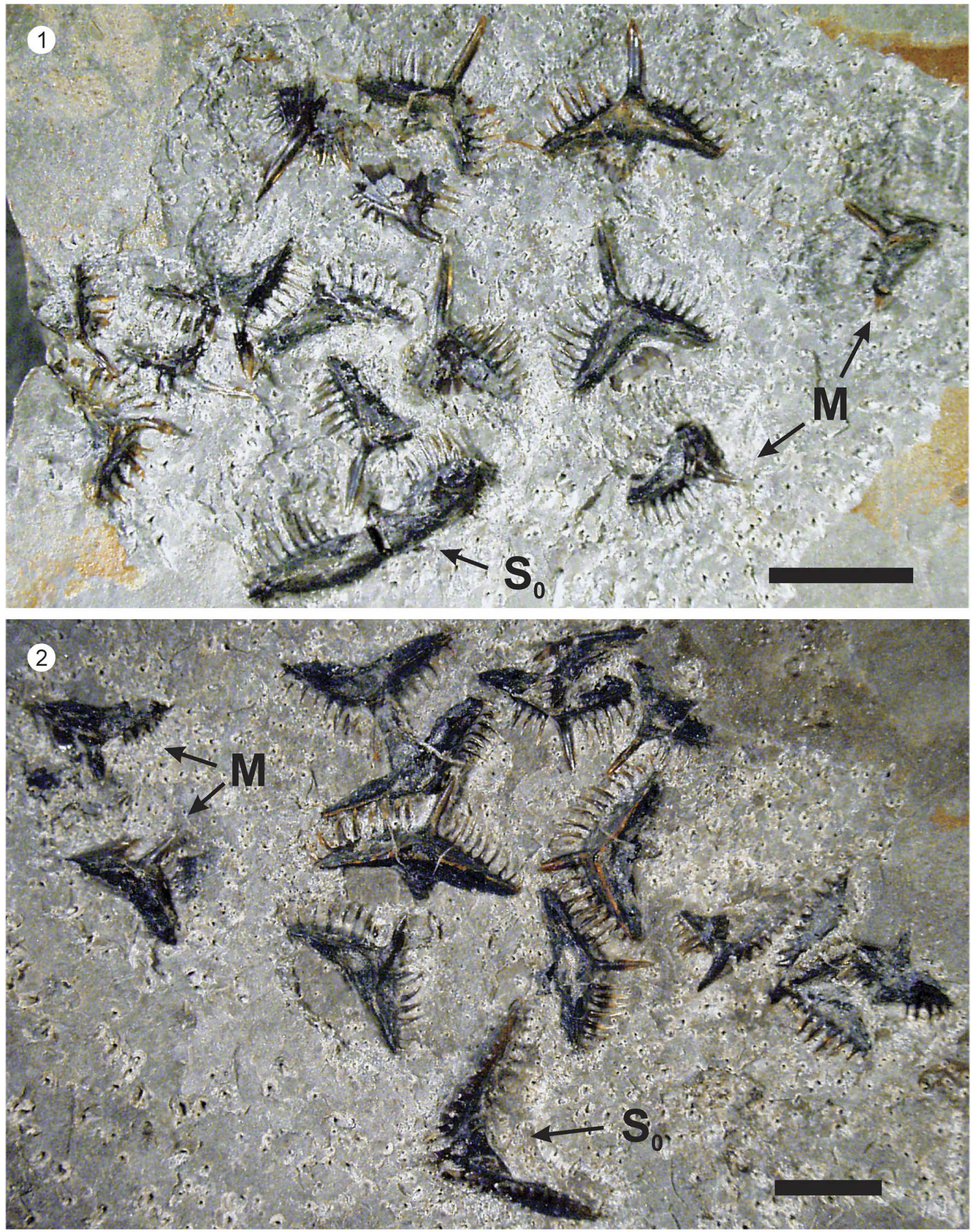

Figure 5. Two apparently complete apparatuses of Iowagnathus grandis n. gen. n. sp. from the Winneshiek Shale, each containing 15 elements, 14 of which are paired and one unpaired. The unpaired $\mathrm{S}_{0}(\mathrm{Sa})$ element and the paired $\mathrm{M}$ elements are marked by arrows in each apparatus. Note the constant locations of the paired M elements in the apparatuses: (1) paratype, SUI 139887 (WS18-60); (2) holotype, SUI 139888 (WS18-266). Scale bar = $2 \mathrm{~mm}$. 


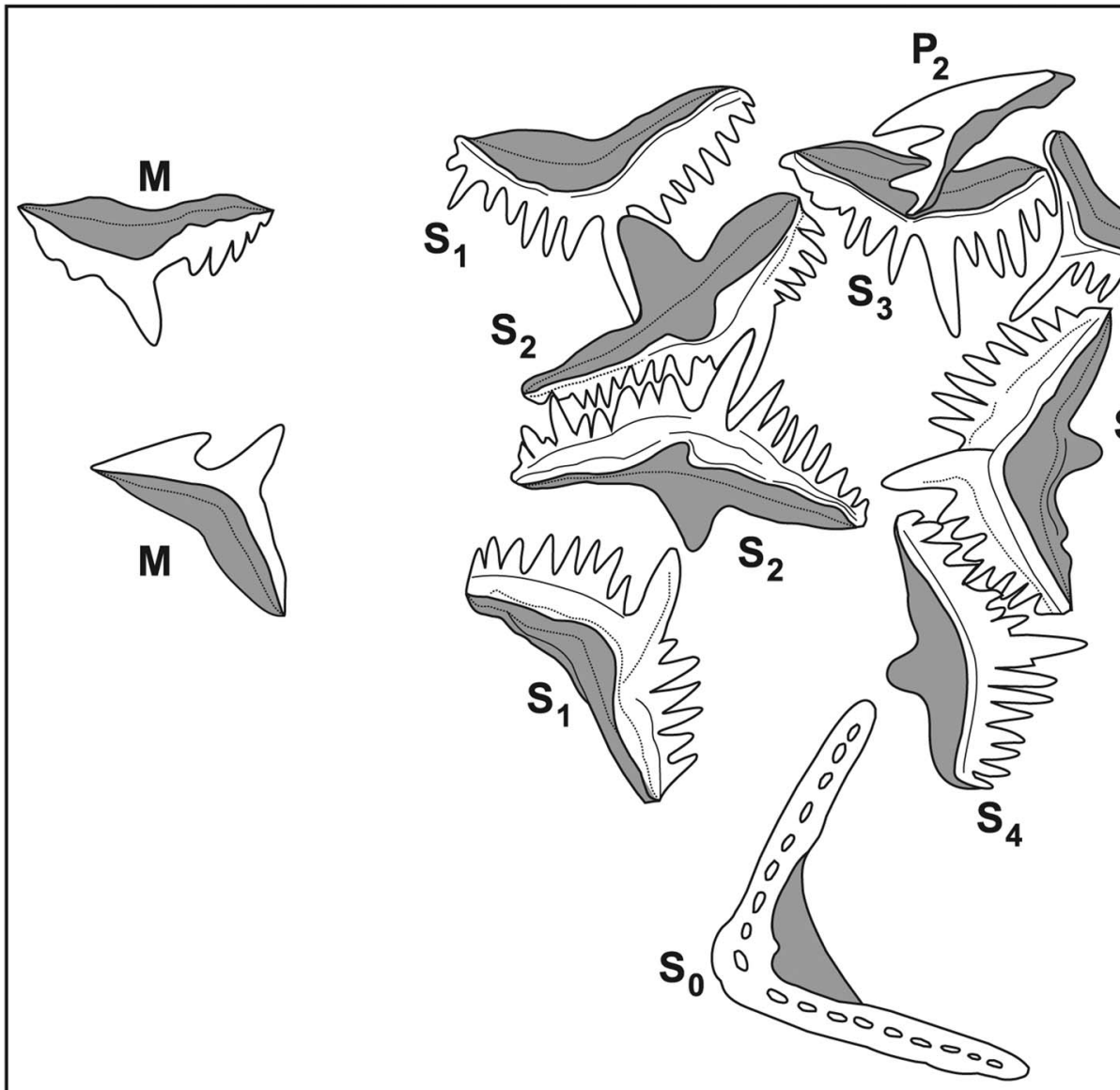

Figure 6. Schematic illustration of the apparatus of the holotype SUI 139888 (WS18-266) of Iowagnathus grandis n. gen. n. sp. showing the element locational notations used in the present study. The apparatus is complete, but the left $\mathrm{P}_{1}$, the right $\mathrm{P}_{2}$, and both $\mathrm{M}$ elements are partly embedded in the shale matrix. Although not shown in this figure, the $S_{3}$ elements have an anterior process, as seen in the paratype illustrated in Figure 5.1.

and a schematic illustration of the element notation is provided in Figure 6. Representative elements are illustrated in Figures 7 and 8.7-8.17. A schematic model of the apparatus elemental distribution is shown in Figure 9.2.

The ramiform, asymmetrical to more or less symmetrical paired $\mathrm{M}, \mathrm{S}$, and $\mathrm{P}$ elements of this species are not conspicuously different in general morphology. The unpaired, essentially symmetrical, and comparatively large $\mathrm{S}_{0}$ element, however, has a highly distinctive alate shape that is reminiscent of the corresponding element in the Devonian genus Apatognathus Branson and Mehl, 1934.

All the elements of Iowagnathus grandis n. gen. n. sp. are multidenticulated, and one of the denticles of each element is usually prominent in size and/or shape. For descriptive purpose, we call this denticle a cusp to distinguish it from others, although a cavity is absent. The $\mathrm{S}_{0}$ element (Figs. 5, 6, 7.1, 8.7-8.9) has a small but identifiable cusp and two symmetrically placed lateral processes that form an angle, which varies from acute to obtuse, or form a wide curve (Fig. 8.7-8.9). There is no anterior or posterior process. The denticles are straight or slightly reclined, of nearly the same length $(\sim 0.5 \mathrm{~mm})$, and sharply pointed and rounded in cross section. However, the two denticles on each lateral process adjacent to the cusp are significantly shorter than the others, resulting in a small gap on each side of the cusp (see Fig. 8.7, 8.9). The length of the lateral processes of the $S_{0}$ element is somewhat variable: the widely arched elements usually have somewhat shorter processes (commonly $<5 \mathrm{~mm}$ long) and fewer denticles (usually $<30$ ). However, a total of 48 denticles were counted in the specimen shown in Figure 8.7. Another $\mathrm{S}_{0}$ element (lower specimen in Fig. 8.8) has a lateral width more than $16 \mathrm{~mm}$, making it one of the largest conodont elements ever recorded.

The 14 paired elements in the I. grandis n. sp. apparatus are roughly similar in morphology, being ramiform with a central cusp and two lateral processes. However, whereas the $\mathrm{S}_{1}, \mathrm{P}_{2}$, and $M$ elements have only two lateral processes, the $S_{2}, S_{3}, S_{4}$, and $P_{1}$ elements have a well-developed denticulated anterior process extended from the cusp (Fig. 7). The anterior process is hidden in the sediment in some specimens, but its presence is revealed in posterior view by a more or less rectangular extension of the basal body (Figs. 6, 7.5). The $S_{2}$ through $S_{4}$ elements, which usually have anterior processes, can be identified based on minor differences in shape and size. For example, the $\mathrm{S}_{3}$ element usually is smaller and has fewer denticles than other $\mathrm{S}$ elements in the apparatus. The paired $\mathrm{P}_{1}$ and $\mathrm{P}_{2}$ elements are essentially similar to the $\mathrm{S}$ elements with multidenticulate processes, but the $\mathrm{P}_{1}$ element is nearly symmetrical and with well-developed denticulated anterior process, and the $\mathrm{P}_{2}$ element is slightly asymmetrical with only two processes. Morphologically the $\mathrm{P}_{2}$ element is close to the $\mathrm{S}_{3}$ 


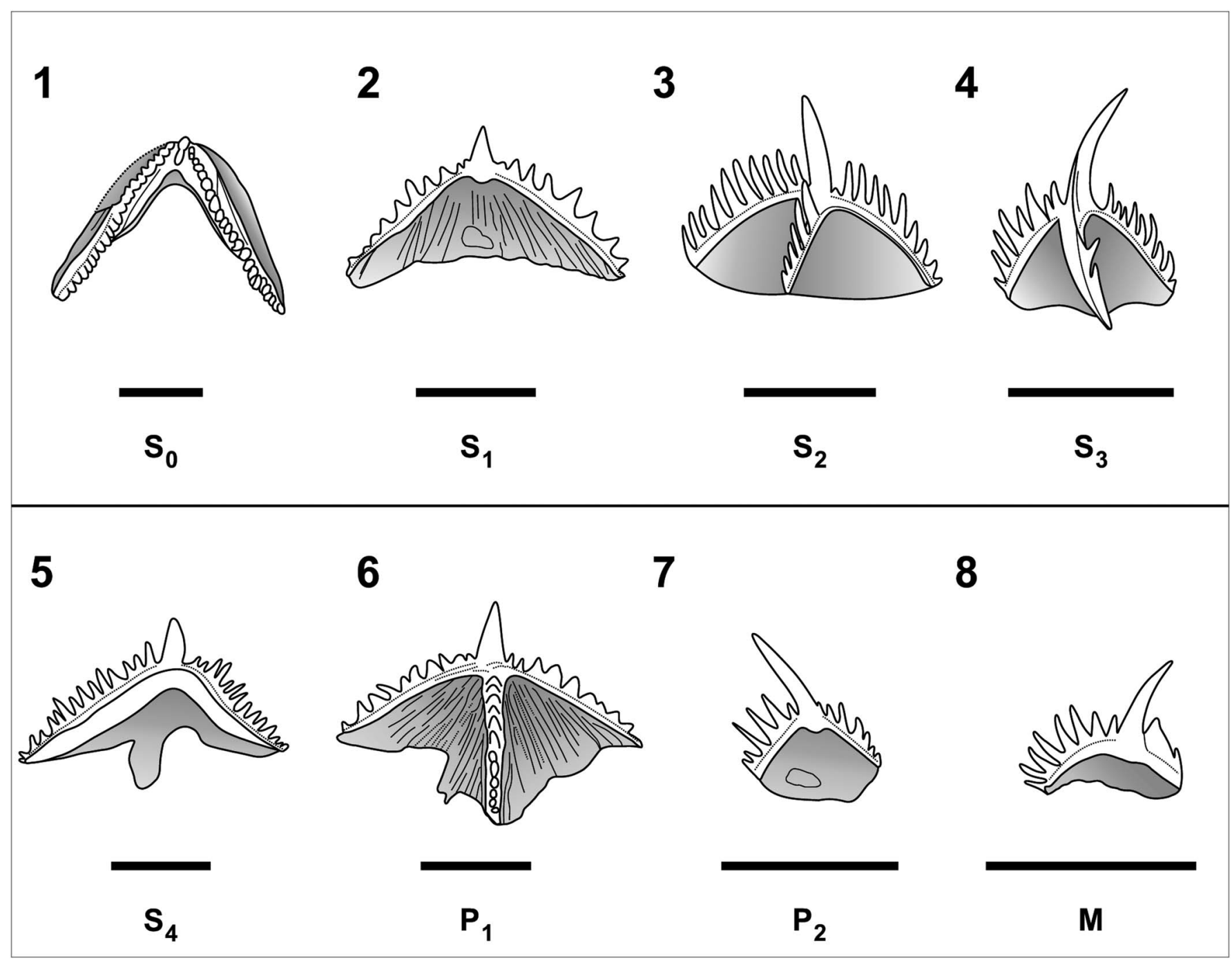

Figure 7. Camera-lucida drawings of elements in the Iowagnathus grandis n. gen. n. sp. apparatus: (1) $\mathrm{S}_{0}$ element, SUI 139894 (W18-246); (2) $\mathrm{S}_{1}$ element, SUI 139904 (WS15-342); (3) S 2 element, SUI 139898A (WS13-656A); (4) $\mathrm{S}_{3}$ element, SUI 139898C (WS13-656C); (5) S 4 element, SUI 139905 (WS17-296), note that this specimen is illustrated in posterior view with a hidden anterior process as a rectangular extension from the cusp; (6) $\mathrm{P}_{1}$ element, SUI 139899 (WS16-80); (7) $\mathrm{P}_{2}$ element, SUI 139900 (WS14-553); (8) M element, SUI 139901 (WS11-342). Scale bars $=2 \mathrm{~mm}$.

element, but the former lacks a third process. The M elements differ from others by their obviously asymmetrical morphology and smaller element size (Figs. 7.8, 8.17). Also, as indicated in
Figure 5 and schematically illustrated in Figures 6 and 9.2, the paired $\mathrm{M}$ elements are always located at one end of its apparatus.

Figure 8. Illustrations of individual elements showing typical element morphologies and microstructures of Archeognathus primus (1-6) and Iowagnathus grandis n. gen. n. sp. (7-19): (1) $\mathrm{P}_{1}$ element of A. primus with a centrally placed wide downward projection ("handle") from the basal body; SUI 139889 (WS12-251); scale bar $=1 \mathrm{~mm} ;(\mathbf{2}, \mathbf{3}) \mathrm{P}_{2}$ elements of A. primus with a narrower downward projection placed near the end of the element; in the element illustrated in Figure 8.3, the amber denticle color has faded to white, and most of the basal body has been dissolved leaving only a carbon film; SUI 139885 (WS12-382) and SUI 139890 (WL58), respectively; scale bar $=1 \mathrm{~mm}$; (4) saw-blade like S element of A. primus with the basal body having a short "ear-like" extension near the end of the element, which is marked by a red arrow; SUI 139891 (WS16-386); scale bar $=2 \mathrm{~mm}$; (5) thin section of a denticle of $A$. primus showing compact growth lamellae; SUI 139892 (WL211); scale bar $=100 \mu \mathrm{m} ;(\mathbf{6})$ thin section of basal body of A. primus showing thick undulate lamellae; SUI 139893 (WL225); scale bar $=100 \mu \mathrm{m}$; (7-9) $\mathrm{S}_{0}$ elements (only the lower one in 8 and 9) showing variations in the element morphology of $I$. grandis $\mathrm{n}$. sp.; SUI 139894 (WS18-246), SUI 139895 (WS13-1), and SUI 139896 (WS18-265), respectively; scale bar $=2 \mathrm{~mm}$ in (7) and (8), $1 \mathrm{~mm}$ in (9); (10) color-faded denticle with fibrous lamellae, which are indicated by white arrows; sample SUI 102854; scale bar $=100 \mu \mathrm{m} ;(\mathbf{1 1}) \mathrm{S}_{1}$ element of $I$. grandis $\mathrm{n}$. sp. with nearly symmetrically placed lateral processes and large, distinctly ornamented basal body; SUI 139897 (WS16-235); scale bar = 1 mm; (12) $\mathrm{S}_{2}$ element of $I$. grandis n. sp. with a slightly curved anterior process; SUI 139898A (WS13-656A); scale bar $=1 \mathrm{~mm}$; (13) $\mathrm{P}_{1}$ element of $I$. grandis $\mathrm{n}$. sp. with symmetrical lateral processes, prominent anterior cusp, and large, strongly ornamented basal body; SUI 139899 (WS16-80); scale bar = 1 mm; (14) posterior view of S element of I. grandis $\mathrm{n}$. sp. with uniformly long denticulated processes and reclined cusp; SUI 139905 (WS17-296); scale bar $=1 \mathrm{~mm}$; (15) $\mathrm{P}_{2}$ element of $I$. grandis $\mathrm{n}$. sp. with short and approximately uniform processes and a long reclined cusp; SUI 139900 (WS14-553); scale bar $=1 \mathrm{~mm}$; (16) S S $_{3}$ element of $I$. grandis n. sp. with prominent, slightly curved, anterior process; SUI 139898C (WS13-656C); scale bar $=1 \mathrm{~mm}$; (17) M element of $I$. grandis n. sp. with asymmetrical lateral processes and prominent cusp; SUI 139901 (WS11-342); scale bar $=1 \mathrm{~mm} ;(\mathbf{1 8})$ thin section of a denticle of I. grandis $\mathrm{n}$. sp. showing very thin growth lamellae; SUI 139902 (WS13-587); scale bar $=100 \mu \mathrm{m}$; (19) thin section of basal body of I. grandis $\mathrm{n}$. sp. illustrating relatively thick undulating lamellae; SUI 139903 (WL208); scale bar $=100 \mu \mathrm{m}$. 




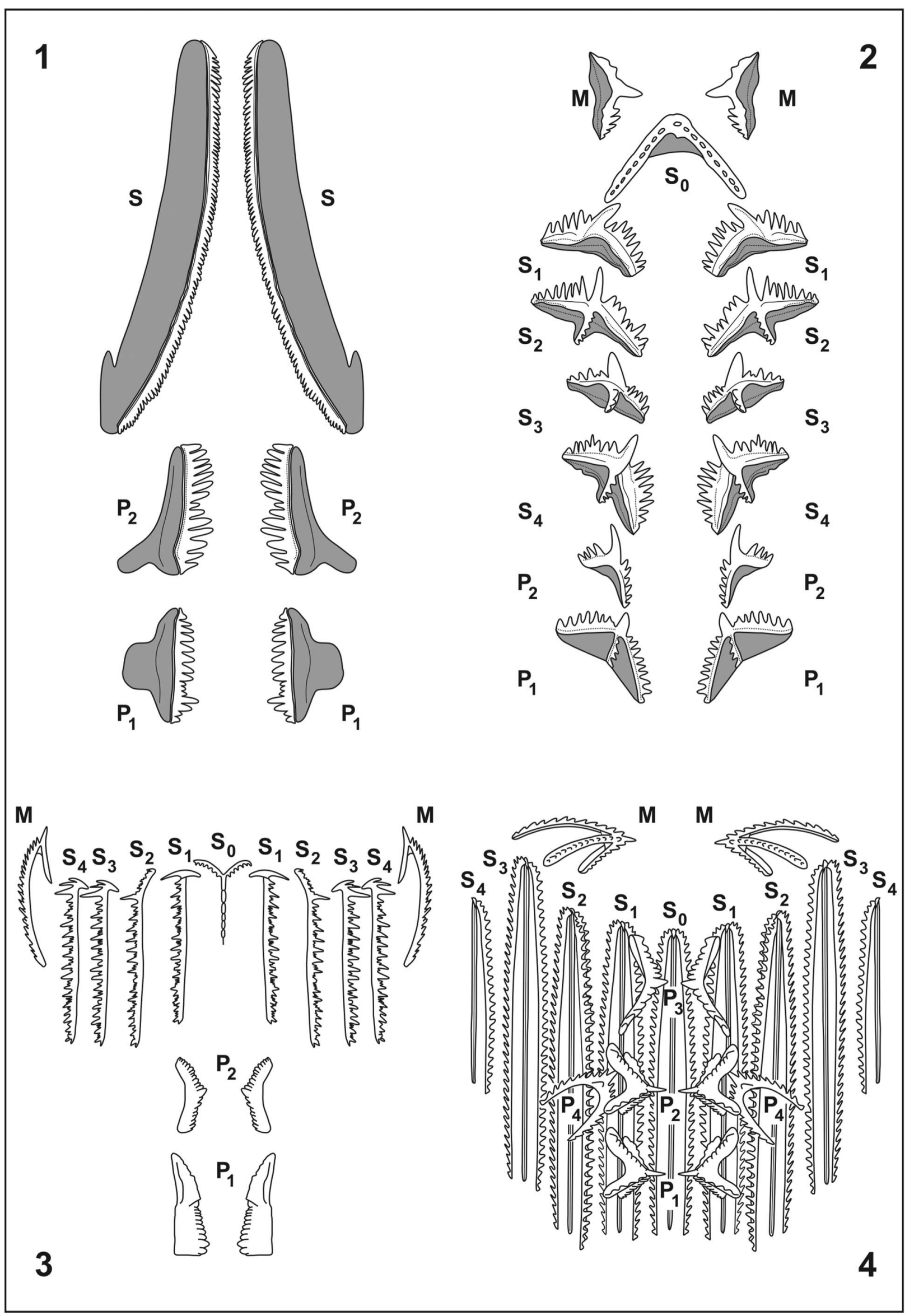


The denticles of the 14 paired elements are more or less reclined and mostly rounded in cross section, and costae or keels may occur, especially on the cusp. However, the denticles of the relatively short process of the $\mathrm{M}$ element are essentially bladeor plate-like in shape (Figs. 7.8, 8.17).

All the paired elements have robust basal bodies. The surface of the bodies has distinct ridge-and-groove structures that radiate from the center of the element (Figs. 7.2, 7.6, 8.11-8.13) similar to those described in Archeognathus primus.

There are some variations in the morphology of the elements of $I$. grandis n. sp., and they show interrelated changes in element size and denticle length. It appears that as the element became larger during ontogeny, the denticles became thicker but comparatively shorter. This might reflect denticle wear, but detailed study of the denticle surfaces is necessary to confirm this.

Remarks.-The erection of a new genus and species for this type of apparatus is based on the absence of any previously named taxon with identical elements. The incompletely known Microcoelodus festivus Moskalenko from the Podkamennaya Tunguska and Moyero Rivers region in Siberia (Moskalenko, 1970), which was based on a single specimen and only illustrated in posterior view, is similar to the $\mathrm{P}_{2}$ element of the present species, but no associated elements of its apparatus have been recorded. Coleodus mirabilis Moskalenko, 1970 has an unusual morphology similar to that of the alate $S_{0}$ element in Iowagnathus grandis n. gen. n. sp., but Moskalenko's (1970) illustrations suggest that this element differs in being albid and having a different type of process denticulation. In general appearance, and particularly denticulation, I. grandis n. sp. is similar to Erismodus? horridus Harris, 1964 from the lower Joins Formation of Oklahoma. However, the illustrations of E.? horridus (Harris, 1964, pl. 1.2a-1.2c) show two types of $\mathrm{S}$ elements that clearly differ from those of $I$. grandis $\mathrm{n}$. $\mathrm{sp}$. in that the third process of the $\mathrm{S}$ elements extends posteriorly from the base of the cusp rather than anteriorly.

\section{Comparison with other conodont apparatuses}

As described above, the elemental component, morphology and structure of Archeognathus primus and Iowagnathus grandis n. gen. n. sp. are significantly different. For comparison, the hypothesized architectures of A. primus and I. grandis n. sp., essentially based on elemental distributions in their apparatuses, are shown in Figure 9.1 and 9.2. Among the small number of natural conodont assemblages described from the Ordovician, none is closely similar to those from the Winneshiek Shale. As far as we are aware, the Winneshiek specimens are the first complete apparatuses with hyaline elements described. Another apparatus with hyaline elements, which was identified as Erismodus quadridactylus, was recorded from the Ordovician of North Dakota, USA (Dhanda, 2004). Judging from the unpublished Ph.D. dissertation by Dhanda (2007), it is far less well preserved compared to the Winneshiek apparatuses and may not be complete. In general architecture, the 6-element apparatus of $A$. primus is unique although it may be interpreted as a much-modified version of the prioniodinid apparatus. In contrast, the 15 element $I$. grandis n. sp. apparatus has a general architecture of prioniodinid type, although individual elements differ markedly in shape from those of, for example, postOrdovician ozarkodinid and polygnathacean apparatuses (e.g., Aldridge et al., 1987). Especially striking is the difference in the morphology and arrangement of the S elements.

A detailed comparison with post-Ordovician apparatuses is beyond the scope of the present paper, so we restrict ourselves to a discussion of two important examples. The first is Promissum pulchrum Kovács-Endrödy from the Upper Ordovician Soom Shale of South Africa (Theron et al., 1990; Aldridge et al., 1995), which was originally thought to be a primitive land plant (Kovács-Endrödy, 1987). Aldridge et al., (1995) recorded 19 elements in its apparatus. The second example, also from the Soom Shale, is Notiodella keblon Aldridge et al., 2013, which has 17 elements in the apparatus. According to Bergström and Ferretti (2015), Notiodella is congeneric with Icriodella Rhodes, 1953, and we use that designation here. The architecture of the Icriodella apparatus (Aldridge et al., 2013, fig. 12) is similar to that of Promissum, except in the case of the $\mathrm{M}$ and $P$ elements, so we do not illustrate it here.

The general elemental distribution of the Archeognathus, Iowagnathus, ozarkodinid, and Promissum apparatuses is schematically compared in Figure 9. The Archeognathus apparatus is much simpler than the others, with a strikingly different template (Fig. 9.1), especially in the presence of only one pair of coleodiform (S) elements, suggesting no obvious relationship to the others. The multidenticulated morphology of the $\mathrm{S}$ elements suggests a similar function to those in Promissum. The apparatus of Iowagnathus n. gen. (Fig. 9.2), in contrast, exhibits a general similarity in organization to both Promissum and the ozarkodinid types of apparatuses. However, Iowagnathus n. gen. has a different basic architecture in that the element pairs appear to be lined up one after the other in two parallel rows rather than being positioned essentially side-byside as is the case with most of the elements in the ozarkodinid (Fig. 9.3) and Promissum (Fig. 9.4) apparatuses. Also, the morphology of the $\mathrm{M}, \mathrm{S}$, and P elements, in particular, is too different to suggest any close relationship between these taxa. In general, the template of the Iowagnathus n. gen. apparatus shows a somewhat closer resemblance to the ozarkodinid type (cf., Mashkova, 1972; Purnell and Donoghue, 1998; Donoghue et al., 2008), which is best known from post-Ordovician strata, than to that of Promissum. As indicated by multiple apparatuses and specimens with paired elements from the Winneshiek Shale, the morphologically similar $\mathrm{S}_{1}$ to $\mathrm{S}_{4}$ elements in Iowagnathus $\mathrm{n}$.

\footnotetext{
Figure 9. Comparison of the architecture of the 6-element apparatus of Archeognathus primus (1), the 15-element apparatus of Iowagnathus grandis n. gen. n. sp. (2), the 15-element apparatus of ozarkodinid type (3), and the 19-element apparatus of Promissum pulchrum (4): Figures (3) and (4) are after Aldridge et al., (1995), Donoghue et al., (2008), and Aldridge et al., (2013). All these figures are based on interpretation of bedding-plane assemblages. The figures of the I. grandis elements are mostly based on SUI 139888 (WS18-266), in which several individual element pairs are readily recognizable. The estimated length of the illustrated apparatuses of A. primus and I. grandis is approximately $20 \mathrm{~mm}$, but an incomplete I. grandis apparatus SUI 139895 (WS13-1) has a length more than $31 \mathrm{~mm}$ with individual elements up to $16 \mathrm{~mm}$ long, suggesting that much larger apparatuses were present. The occurrence of some element pairs in clusters, and the symmetrical arrangement of elements, indicate that they likely had a food-handling function.
} 
gen., which occur between the $\mathrm{M}$ and $\mathrm{P}$ elements, suggest that they may have had a similar function as the P elements.

The apparatus of Iowagnathus n. gen. also differs in several significant respects from the reconstructed apparatuses of the Silurian genera Pterospathodus (Barrick and Klapper, 1976), Astropentagnathus (Armstrong, 1990), Apsidognathus (Armstrong, 1990), and Aulacognathus (Armstrong, 1990), indicating no close evolutionary relationships to these genera. Thus, both Archeognathus and Iowagnathus n. gen. appear to be isolated taxonomically from other genera. This taxonomic isolation is consistent with the fact that hyaline conodonts are not recorded from the latest Ordovician, although they are well represented in Middle and early Late Ordovician faunas.

\section{Discussion}

Exceptionally preserved apparatuses of Archeognathus primus and Iowagnathus grandis n. gen. n. sp. from the Winneshiek Shale provide unusual material for the reconstruction of their apparatus architecture and the determination of their affinity. In reconstructing apparatus architecture, it is obviously important to investigate the degree of post-mortem movement of individual elements. Where no movement has occurred, paired elements occupy consistent positions and the arrangement of the elements follows a particular pattern. Unfortunately, such specimens have not been available for many described apparatuses and their architectures have been inferred based on available evidence. Complete conodont apparatuses are very rare in the lower Paleozoic and virtually all are preserved in two dimensions on bedding planes, except the remarkable Upper Devonian Palmatolepis apparatus described by Lange (1968, pl. 1). Although element movement may occur during preservation, many elements in bedding-plane assemblages of both Archeognathus and Iowagnathus $\mathrm{n}$. gen. from the Winneshiek Shale are arranged in morphologically similar pairs, some of which are located close together. This provides strong indication of little movement of these elements, especially as consistent patterns are evident in several apparatuses.

As described before, the two pairs of shorter archeognathiform elements in the Archeognathus primus apparatus are regarded as homologous with the P elements in Lange's Palmatolepis apparatus and in numerous preserved apparatuses from the Pennsylvanian of Illinois (Aldridge et al., 1987), and the elongated coleodiform elements as $\mathrm{S}$ elements. The spatial arrangement of elements in the A. primus apparatus is best displayed in the specimens shown by Figures 2.1 and 2.2, in which the elements are consistently arranged, from left to right in the pictures, as paired $\mathrm{P}_{1}, \mathrm{P}_{2}$, and $\mathrm{S}$ elements. The distribution pattern of elements in the apparatus of I. grandis n. sp. is represented by the specimens shown in Figure 5, in which the location of the paired $\mathrm{M}$ elements always at one end of the apparatus and the $\mathrm{P}$ elements at the other is reminiscent of many other genera (Purnell et al., 2000). In addition to the illustrated specimens, similar elemental orientations of both taxa repeatedly occur in our collection, revealing consistent patterns that provide useful information for apparatus architecture reconstructions.

The unusual morphology of the hyaline archeognathiform (P) elements in Archeognathus has prompted several authors to discuss their classification, affinity, morphology, and function.
Based on its "jaw like" appearance, the archeognathiform element, which was designated as the holotype of A. primus, was referred to as a toothed fish jaw or that of some other vertebrate (e.g., Miller et al., 1947; Barskov et al., 1982). Branson and Mehl (1944) grouped conodonts with a "jaw structure" and fibrous denticles into the family Coleodontidae, to which they referred the genera Coleodus, Erismodus, and Neocoleodus. Based on an investigation of ultrastructures, Barnes et al., (1973) divided their Ordovician conodonts into two major groups, hyaline conodonts and cancellate conodonts. In addition to other microscopic features, these two groups are mainly characterized by the presence or absence of white matter. Klapper and Bergström (1984) considered the archeognathiform elements to have functioned as teeth and assigned them to conodonts, but they found no evidence of a vertebrate affinity. Based on the chemical composition and unusual fibrous structure of the elements, these fossils were regarded as possible vertebrates by Rhodes and Wingard (1957). Barskov et al., (1982) and Sansom et al., (1994) suggested the presence of vertebrate bone structures in such fossils, especially Coleodus, Neocoleodus, and Chirognathus. All these studies were based on isolated elements, some of them incomplete. Because of their uncertain affinity, Clark et al., (1981) listed these fossils as family Unknown (Neocoleodus) or Problematic Taxa (Archeognathus and Coleodus), and Sweet (1988) listed Archeognathus under order Unknown.

Lindström (1964) studied the plastic-embedded holotype of A. primus Cullison (1938, pl. 29, figs. 16a, b) and argued that its structure "is entirely different from the structure we always find in conodonts, and there is no reason to believe that Archeognathus, fish or no fish, is closely related to conodonts" (Lindström, 1964, p. 122). Many other authors also studied such fossils, but concluded that there is no morphological or other evidence that eliminates Archeognathus from conodonts. Sweet (1988, p. 123) considered such fossils, especially Archeognathus, to "clearly exhibit the internal structure of conodonts" and remarked that "the basal structures have no counterpart in the Conodonta. No relationship to other groups is apparent", thus they "might represent a separate class of the Conodonta." The detailed micro- and macromorphology of Archeognathus were studied by Klapper and Bergström (1984), and the results were consistent with a conodont affinity, but they noted that "the fibrous conodonts apparently are a rather specialized group" (Klapper and Bergström, 1984, p. 973). This study supports the identity of the Winneshiek specimens of Archeognathus and Iowagnathus $\mathrm{n}$. gen. as true conodonts with particular element structures and arrangements in their apparatuses. However, the morphology and arrangement of elements in apparatuses of both taxa are significantly different from most euconodonts. Other groups, such as hagfish, also have a laterally operating feeding apparatus. Thus, future discoveries and investigations may clarify the phylogenetic classification of these unusual Winneshiek taxa.

Archeognathus and Iowagnathus n. gen. share several unusual morphological features, perhaps the most prominent one being the large basal bodies with their ridge-and-groove surface. Although the basal bodies of both taxa differ from those in other conodonts, as discussed above, we do not regard this as sufficient to separate them from Conodonta. However, 
such basal body surface ornamentation is not obvious in all Winneshiek elements of these taxa and it has not been observed in representatives of other species. Nor has it been observed in specimens of A. primus from the type stratum Dutchtown Formation of Missouri, which have quite smooth basal body surfaces (e.g., Klapper and Bergström, 1984, figs. 3, 5A). The latter is also the case in the specimens from the Harding Sandstone of Colorado (Miller, 1969) and the lower Chickamauga Formation of Alabama (Mosher and Bodenstein, 1969). It is commonly accepted that basal bodies and basal funnels were parts of the conodont element in life, but that their different chemistry made them susceptible to dissolution during the fossilization process. Such basal structures are missing in most conodont collections from carbonate strata, but when present, they tend to occur in a variety of taxa (e.g., Sweet and Bergström, 1962). The preservation environment of the shale-embedded fauna of the Winneshiek Konservat-Lagerstätte was very unusual. The presence of the conspicuous surface structure of the basal body may be a preservational artifact, perhaps a shrinkage feature, which reflects an early step in the dissolution process. However, further study is needed to clarify the nature of these remarkable basal body surface structures.

Both Archeognathus and Iowagnathus n. gen. show the same distinct growth lamellae, which are thin and compact in the denticles, but thick and massive in the basal bodies (Fig. 8.5, 8.6, 8.18, 8.19). Although lamellae are present in all conodonts, in our thin sections of Archeognathus and Iowagnathus n. gen. elements, we have not observed continuous lamellae between the crowns and the basal bodies as described in some albid conodonts (Müller, 1981). This consistent discontinuity suggests that this feature is original and not a result of organic matter shrinkage during diagenesis (Müller and Nogami, 1971). However, some Winneshiek conodont elements do show diagenetic effects, which occur as conspicuous fading of crown denticles and dissolution of basal body material into carbonaceous films (Fig. 8.3). This suggests that, as in other conodonts, the chemical composition of the crown and the basal body is different. Another characteristic feature, which is shared with some other hyaline conodonts, is that denticles of both Archeognathus and Iowagnathus n. gen. are fibrous (Fig. 8.10) and white matter is very rare or absent. These similarities may suggest a relationship between the two taxa.

Although soft tissues of Archeognathus and Iowagnathus $\mathrm{n}$. gen. have not been recognized in current Winneshiek specimens, these giant hyaline conodont elements with their robust basal bodies are clearly different from those of the small conodont animals with preserved soft tissues found in the Lower Carboniferous of Scotland (e.g., Briggs et al., 1983; Aldridge et al., 1986, 1993). The suprafamily classification of the two Winneshiek genera described herein remains undetermined pending further study.

\section{Conclusions}

The Middle Ordovician Winneshiek Konservat-Lagerstätte in Iowa contains a variety of unusually well-preserved conodonts, including many natural assemblages with elements preserved in three dimensions. Although no soft parts have been found associated with these natural assemblages, these fossil specimens provide important insights into their apparatus architecture and conodont element structures. In the taxa described herein, the apparatuses of the 6-element Archeognathus and the 15 element Iowagnathus n. gen. are characterized by giant element sizes and the unusual preservation of robust basal bodies. Such basal bodies are unknown in the elements of previously described lower Paleozoic conodont apparatuses, but occur in single elements from a few Ordovician faunas (e.g., Cullison, 1938; Jensen and Miller, 1969; Moskalenko, 1970, 1983; Klapper and Bergström, 1984). The detailed features of the elements from the Winneshiek Konservat-Lagerstätte indicate that they are special types of conodonts, and their consistent elemental distribution in apparatuses provide exceptional materials for the reconstruction of their apparatus architectures.

\section{Acknowledgements}

G. Klapper, S. Leslie, J. Miller, J. Repetski, and an anonymous reviewer provided valuable comments during the course of this study. R. Rowden, T. Marshall, C. Davis, D. Campbell, and C. Monson assisted in the excavation of the Winneshiek Shale outcrop. Graduate students M. Spencer, J. McHugh, E. Wilberg, H. Zou, M. Tibbits, W. Cao, J. Matzke and undergraduate students K. McVey, D. McKay, M. Behling, B. Dye, J. Hansen, B. Neale, C. Kuempel, E. Greaves, K. Parson, and T. Maher helped with fossil search and sample preparation in the laboratory. Camera-lucida images were drawn by M. Liu. Thin sections were prepared by M. Wortel. P. Kerr helped with figure editing. The project was supported by NSF grants EAR 0921245 and EAR 0922054. This paper is a contribution to the UNIMORE-FAR2014 Project ROSAE (Responsible AF) and to the IGCP Projects 591 and 653.

\section{References}

Aldridge, R.J., Briggs, D.E.G., Clarkson, E.N.K., and Smith, M.P., 1986 The affinities of conodonts-new evidence from the Carboniferous of Edinburgh, Scotland: Lethaia, v. 19, p. 279-291.

Aldridge, R.J., Smith, M.P., Norby, R.D., and Briggs, D.E.G., 1987, The architecture and function of Carboniferous polygnathacean conodont apparatuses, in Aldridge, R.J., ed., Palaeobiology of Conodonts: Chichester, Ellis Horwood Limited, p. 63-75.

Aldridge, R.J., Briggs, D.E.G., Smith, M.P., Clarkson, E.N.K., and Clark, N.D.L., 1993, The anatomy of conodonts: Philosophical Transactions of the Royal Society, London, Series B, v. 340, p. 405-421.

Aldridge, R.J., Purnell, M.A., Gabbott, S.E., and Theron, J., 1995, The apparatus architecture and function of Promissum pulchrum Kovács-Endrödy (Conodonta, Upper Ordovician) and the prioniodontid plan: Philosophical Transactions of the Royal Society of London, Series B, v. 347, p. 275-291.

Aldridge, R.J., Murdock, J.E., Gabbott, S.E., and Theron, J.N., 2013 , A 17-element conodont apparatus from the Soom Shale Lagerstätte (Upper Ordovician), South Africa: Palaeontology, v. 56, p. 261-276.

An, T., et al., 1983, The conodonts of north China and the adjacent regions: Beijing, Science Press, 223 p. [in Chinese].

Andrews, H.E., 1967, Middle Ordovician conodonts from the Joachim Dolomite of eastern Missouri: Journal of Paleontology, v. 41, p. 881-901.

Armstrong, H.A., 1990, Conodonts from the Upper Ordovician - Lower Silurian carbonate platform of North Greenland: Grønlands Geologiske Unders $\varnothing$ kelse Bulletin, v. 159, p. 1-151.

Barnes, C.R., and Poplawski, M.L.S., 1973, Lower and Middle Ordovician conodonts from the Mystic Formation, Quebec, Canada: Journal of Paleontology, v. 47, p. 760-790.

Barnes, C.R., Sass, D.B., and Monroe, E.A., 1973, Ultrastructure of some Ordovician conodonts, in Rhodes, F.H.T., ed., Conodont Paleozoology: Geological Society of America Special Paper 141, p. 1-30. 
Barrick, J.E., and Klapper, G., 1976, Multielement Silurian (late Llandoverian Wenlockian) conodonts from the Clarita Formation, Arbuckle Mountains, Oklahoma, and phylogeny of Kockelella: Geologica et Paleontologica, v. 10, p. $59-100$.

Barskov, I.S., Moskalenko, T.A., and Starostina, L.P.T., 1982, New evidence for the vertebrate nature of the conodontophorids: Paleontological Journal (Translated), v. 1, p. 82-90.

Bauer, J.A., 1987, Conodonts and conodont biostratigraphy of the McLish and Tulip Creek formations (Middle Ordovician) of south-central Oklahoma: Oklahoma Geological Survey Bulletin, v. 141, $58 \mathrm{p}$.

Bauer, J.A., 1989, Conodont biostratigraphy and paleoecology of Middle Ordovician rocks in eastern Oklahoma: Journal of Paleontology, v. 63, p. $92-107$.

Bauer, J.A., 2010, Conodonts and conodont biostratigraphy of the Joins and Oil Creek formations, Arbuckle Mountains, south-central Oklahoma: Oklahoma Geological Survey Bulletin, v. 150, 44 p.

Bergström, S.M., 1980, Whiterockian (Ordovician) conodonts from the Hølonda Limestone of the Trondheim region, Norwegian Caledonides: Norsk Geologisk Tidsskrift, v. 59, p. 295-307.

Bergström, S.M., and Ferretti, A., 2015, Conodonts in the Upper Ordovician Keisley Limestone of northern England: Taxonomy, biostratigraphical significance and biogeographical relationships: Papers in Palaeontology, v. 1, p. $1-32$.

Bergström, S.M., Carnes, J.B., Ethington, R.L., Votaw, R.B., and Wigley, P.B., 1974, Appalachignathus, a new multielement conodont genus from the Middle Ordovician of North America: Journal of Paleontology, v. 48 , p. $227-235$.

Branson, E.B., 1944, The Geology of Missouri: The University of Missouri Studies, v. 19 , no. 3 , p. $1-535$.

Branson, E.B., and Mehl, M.G., 1933, Conodont Studies Number 1: conodonts from the Harding Sandstone of Colorado: The University of Missour Studies, v. 8, p. 19-38.

Branson, E.B., and Mehl, M.G., 1934, Conodont Studies Number 3: conodonts from the Grassy Creek Shale of Missouri: The University of Missouri Studies, v. 8, p. 171-259.

Branson, E.B., and Mehl, M.G., 1944, Conodonts, in Shimer, H.W., and Shrock, R.R., eds., Index Fossils of North America: Cambridge, New York, M.I.T. Press, p. 235-246.

Briggs, D.E.G., Clarkson, E.N.K., and Aldridge, R.J., 1983, The conodont animal: Lethaia, v. 16, p. 1-14.

Briggs, D.E.G., Liu, H.P., McKay, R.M., and Witzke, B.J., 2015 [2016], Bivalved arthropods from the Middle Ordovician Winneshiek Lagerstätte, Iowa, USA: Journal of Paleontology, v. 89, p. 991-1006.

Clark, D.L., et al., 1981, Systematic descriptions, in Robison, R.A., ed., Treatise on Invertebrate Paleontology, Pt. W Miscellanea, Supplement 2, Conodonta: Boulder, Colorado and Lawrence, Kansas, Geological Society of America and the University of Kansas, W111-W180.

Cullison, J.S., 1938, Dutchtown fauna of southeastern Missouri: Journal of Paleontology, v. 12, p. 219-228.

Dhanda, R., 2004, The apparatus architecture of the prioniodinid conodont Erismodus quadridactylus and its implications: Palaeontology Newsletter, v. 57, p. $117-118$.

Dhanda, R., 2007, The homologies and phylogenetic relationships of prioniodinin conodonts [Ph.D. dissertation]: Birmingham, University of Birmingham, $259 \mathrm{p}$.

Donoghue, P.C.J., Purnell, M.A., Aldridge, R.J., and Zhang, S., 2008, The Interrelationships of 'complex' conodonts (Vertebrata): Journal of Systematic Palaeontology, v. 6, no. 2, p. 119-153.

Dzik, J., 1978, Conodont biostratigraphy and paleogeographical relations of the Ordovician Mójcza Limestone (Holy Cross Mts. Poland): Acta Palaeontologica Polonica, v. 23, p. 51-72.

Dzik, J., 1994, Conodonts of the Mójcza Limestone, in Dzik, J., Olempska, E., and Pisera, A., eds., Ordovician Carbonate Platform Ecosystem of the Holy Cross Mountains: Palaeontologia Polonica, v. 53, p. 43-128.

Eichenberg, W., 1930, Conodonten aus dem Culm des Harzes: Paläontologische Zeitschrift, v. 12, p. 177-182.

Ethington, R.L., and Clark, D.L., 1981, Lower and Middle Ordovician conodonts from the Ibex area, western Millard County, Utah: Brigham Young University Geology Studies, v. 28, no. 2, p. 1-155.

Ethington, R.L, Droste, J.B., and Rexroad, C.B., 1986, Conodonts from subsurface Champlainian (Ordovician) rocks of eastern Indiana: Indiana Department of Natural Resources, Geological Survey Special Report 37, $32 \mathrm{p}$.

Furnish, W.M., 1938, Conodonts from the Prairie du Chien beds of the Upper Mississippi Valley: Journal of Paleontology, v. 12, p. 318-340.

Graves, R.W., and Ellison, S.P. Jr., 1941, Ordovician conodonts from the Marathon Basin, Texas: University of Missouri School of Mines and Metallurgy Bulletin, Technical Series, v. 14, no. 2, p. 1-25.
Harris, R.W., 1964, Erismodid conodonts in Simpson (Ordovician) of Oklahoma: Oklahoma Geology Notes, v. 24, p. 171-177.

Jensen, D., and Miller, H.W., 1969, A second specimen of Youngquistina mitteni from the Harding Sandstone (Ordovician) of Colorado: Transactions of the Kansas Academy of Science, v. 72, p. 527-532.

Jin, J., Harper, D.A.T., Cocks, L.R.M., McCusland, P.J.A., Rasmussen, C.M.Ö. and Sheehan, P.M., 2013, Precisely locating the Ordovician equator in Laurentia: Geology, v. 41, p. 107-110.

Klapper, G., and Bergström, S.M., 1984, The enigmatic Middle Ordovician fossil Archeognathus and its relations to conodonts and vertebrates: Journal of Paleontology, v. 58, p. 949-976.

Koontz, H., and McKay, R.M., 2013, Iowa meteorite crater confirmed: U.S. Geological Survey Newsroom online publication, accessible at: https://archive.usgs.gov/archive/sites/www.usgs.gov/newsroom/article. asp-ID $=3521 . h$ tml.

Kovács-Endrödy, E.E., 1987, The earliest known vascular plant, or a possible ancestor of vascular plants in the flora of the Lower Silurian Cedarberg Formation, Table Mountain Group, South Africa: Annals of the Geological Survey of South Africa, v. 20, p. 93-118.

Lamsdell, J.C., Briggs, D.E.G., Liu, H.P., Witzke, B.J., and McKay, R.M. 2015a, A new Ordovician arthropod from the Winneshiek Lagerstätte of Iowa (USA) reveals the ground plan of eurypterids and chasmataspidids: The Science of Nature, v. 102, 63, p. 1-8. DOI: 10.1007/s00114-0151312-5.

Lamsdell, J.C., Briggs, D.E.G., Liu, H.P., Witzke, B.J., and McKay, R.M., 2015b, The oldest described eurypterid: a giant Middle Ordovician (Darriwilian) megalograptid from the Winneshiek Lagerstätte of Iowa: BMC Evolutionary Biology, v. 15, 169, p. 1-31. DOI: 10.1186/s12862-015-0443-9.

Lange, F.G., 1968, Conodonten-Gruppenfunde aus Kalken des tieferen Oberdevon: Geologica et Palaeontologica, v. 2, p. 37-57.

Lindström, M., 1964, Conodonts: Amsterdam, Elsevier Publishing Company, $196 \mathrm{p}$.

Liu, H.P., McKay, R.M., Young, J.N., Witzke, B.J., McVey, K., and Liu, X., 2006, A new Lagerstätte from the Middle Ordovician St. Peter Formation in northeast Iowa: Geology, v. 34, p. 969-972.

Liu, H.P., McKay, R.M., Young, J.N., Witzke, B.J., McVey, K.J., and Liu, X., 2007, The Winneshiek Lagerstätte: Acta Palaeontologica Sinica, v. 46, supplement, p. 282-285.

Liu, H.P., McKay, R.M., Witzke, B.J., and Briggs, D.E.G., 2009, The Winneshiek Lagerstätte, Iowa, USA and its depositional environments: Geological Journal of China Universities, v. 15, p. 285-295. [In Chinese with English summary].

Liu, H.P., Witzke, B.J., Briggs, D.E.G., McKay, R.M., and Spencer, M., 2011, A giant prioniodinid conodont from the Middle Ordovician Winneshiek Lagerstätte of northeastern Iowa, USA: Geological Society of America Abstracts with Programs, v. 43, no. 5, p. 429.

Liu, H.P., Bergström, S.M., Witzke, B.J., Briggs, D.E.G., and McKay, R.M., 2015, Conodont apparatuses from the Middle Ordovician Winneshiek Shale, Iowa, USA: Geological Society of America Abstracts with Programs, v. 47 , no. 7 , p. 136

Mashkova, T.V., 1972, Ozarkodina steinhornensis (Ziegler) apparatus, its conodonts and biozone: Geologica et Palaeontologica, SB, v. 1, p. 81-90.

McKay, R. M., Liu, H.P., Witzke, B.J., French, B. M., and Briggs, D.E.G., 2011, Preservation of the Middle Ordovician Winneshiek Shale in a probable impact crater: Geological Society of America Abstracts with Programs, v. 43, no. 5, p. 189.

Miller, H.W., 1969, Youngquistina mitteni, new genus and species of Chordate from the Harding Sandstone (Ordovician) of Colorado: Transactions of the Kansas Academy of Science, v. 71, p. 504-508.

Miller, H.W., Cullison, J.S., and Youngquist, W.L., 1947, Lower Ordovician fish remains from Missouri: American Journal of Science, v. 245, p. 31-34.

Mosher, L.C., and Bodenstein, F., 1969, A unique conodont basal structure from the Ordovician of Alabama: Geological Society of America Bulletin, v. 80, p. 1401-1402.

Moskalenko, T., 1970, Conodonts from the Krivolutz Stage (Middle Ordovician), Siberian Platform: Academiya NAUK Trudy, v. 61, p. 1-116. [In Russian].

Moskalenko, T., 1973, Conodonts of the Middle and Upper Ordovician of the Siberian Platform: Academiya NAUK SSR, Sibirskoe otdelenie. Instituta Geologiii i Geofiziki Trudfy, v. 137, p. 1-145. [In Russian].

Moskalenko, T., 1983, Conodonts and biostratigraphy in the Ordovician of the Siberian Platform: Fossils and Strata, v. 15, p. 87-94.

Mound, M.C., 1965, A conodont fauna from the Joins Formation (Ordovician), Oklahoma: Tulane Studies in Geology, v. 4, p. 1-46.

Müller, K.J., 1981, Micromorphology of elements: internal structure, in Robison, R.A., ed., Treatise on Invertebrate Paleontology, Pt. W Miscellanea, Supplement 2: Conodonta, Boulder, Colorado and Lawrence, Kansas, Geological Society of America and the University of Kansas, p. W20-W41. 
Müller, K., and Nogami, Y., 1971, Über den Feinbau der Conodonten: Memoir of the Faculty of Science Kyoto University, Series Geology Mineralogy, v. 38 , p. $1-88$.

Niocaill, C.M., van den Plum, B.A., and van der Voo, R., 1997, Ordovician paleogeography and the evolution of the Iapetus Ocean: Geology, v. 25, p. $159-162$.

Nowak, H., Harvey, T.H.P., Liu, H., McKay, R.M., and Servais, T., 2015, Exceptionally preserved arthropodan microfossils from the Winneshiek Lagerstätte: $59^{\text {th }}$ Palaeontological Association Annual Meeting, Programme, Abstracts and AGM Papers, p. 72.

Purnell, M.A., 1994, Skeletal ontogeny and feeding mechanisms in conodonts: Lethaia, v. 27, p. 129-138.

Purnell, M.A., 1995, Large eyes and vision in conodonts: Lethaia, v. 28, p. $187-188$.

Purnell, M.A., and Donoghue, P.C.J., 1998, Architecture and functional morphology of the skeletal apparatus of ozarkodinid conodonts: Palaeontology, v. 41 , pt. 1 , p. $57-102$.

Purnell, M.A., Donoghue, P.C.J., and Aldridge, R.J., 2000, Orientation and anatomical notation in conodonts: Journal of Paleontology, v. 74, p. 113-122.

Repetski, J.E., 1997, Conodont age constraints on the Middle Ordovician black shale within the Ames structure, Major County, Oklahoma, in Johnson, K.S., and Campbell, J.A., eds., Ames Structure of Northwest Oklahoma and Similar Features: Origin and Petroleum Production (1995 Symposium): Oklahoma Geological Survey Circular 100, p. 363-369.

Rexroad, C.B., Droste, J.B., and Ethington, R.L., 1982, Conodonts from the Everton Dolomite and the St. Peter Sandstone (Lower Middle Ordovician) in a core from southwestern Indiana: Indiana Department of Natural Resources, Geological Survey Occasional Paper 39, p. 1-13.

Rhodes, F.H.T., 1953, Some British Lower Palaeozoic conodont faunas: Philosophical Transactions of the Royal Society London Series B, v. 237, p. 261-334.

Rhodes, F.H.T., and Wingard, P.S., 1957, Chemical composition, microstructure, and affinities of the neurodontiformes: Journal of Paleontology, v. 34 , p. $448-454$.

Ross, R.J. Jr., et al., 1982, The Ordovician System in the United States, correlation chart and explanatory notes: International Union of Geological Sciences Publication, no. 12, p. 1-93.

Sansom, I.J., Smith, M.P., and Smith, M.M., 1994, Dentine in conodonts: Nature, v. 368 , p. 591.

Stauffer, C.R., 1935, Conodonts of the Glenwood beds: Geological Society of America Bulletin, v. 46, p. 125-168.

Stewart, I., and Nicoll, R.S., 2003, Fifteen element septemembrate apparatus structure of the early Ordovician conodont Oepikodus evae Lindström from Australia and Sweden: Courier Forschung institut Senckenberg, v. 245, p. 361-387.
Sweet, W.C., 1982, Conodonts from the Winnipeg Formation (Middle Ordovician) of the northern Black Hills, South Dakota: Journal of Paleontology, v. 56, p. 1029-1049.

Sweet, W.C., 1988, The Conodonta: morphology, taxonomy, paleoecology, and evolutionary history of a long-extinct animal phylum: New York and Oxford, Oxford University Press, 212 p.

Sweet, W.C., and Bergström, S.M., 1962, Conodonts from the Pratt Ferry Formation (Middle Ordovician) of Alabama: Journal of Paleontology, v. 36, p. 1214-1252.

Theron, J.N., Richards, R.B., and Aldridge, R.J., 1990, Bedding plane assemblages of Promissum pulchrum, a new giant Ashgill conodont from the Table Mountain Group, South Africa: Palaeontology, v. 33, p. 577-594.

Tolmacheva, T., and Purnell, M., 2002, Apparatus composition, growth, and survivorship of the Lower Ordovician conodont Paracordylodus gracilis Lindström, 1955: Palaeontology, v. 45, p. 209-228.

Wang, Z., Bergström, S.M., Zhen, Y., Zhang, Y., and Wu, R., 2014, A revision of the Darriwilian biostratigraphic conodont zonation in Tangshan, Hebei Province based on new conodont collections: Acta Palaeontologica Sinica, v. 53, p. 1-15. [In Chinese with English summary].

Webers, G.F., 1966, The Middle and Upper Ordovician conodont faunas of Minnesota: Minnesota Geological Survey Special Publication SP 4, p. $1-123$.

Witzke, B.J., 1990, Palaeoclimatic constraints for Palaeozoic palaeolatitudes of Laurentia and Euamerica, in McKerrow, W.S., and Scotese, C., eds., Palaeozoic Palaeogeography and Biogeography: Geological Society (London) Memoir, v. 12, p. 57-73.

Witzke, B.J., and Metzger, R.A., 2005, Ordovician conodonts and stratigraphy of the St. Peter Sandstone and Glenwood Shale, central United States: Bulletins of American Paleontology, v. 369, p. 53-90.

Witzke, B.J., McKay, R.M., Liu, H.P., and Briggs, D.E.G., 2011, The Middle Ordovician Winneshiek Shale of northeast Iowa-correlation and paleogeographic implications: Geological Society of America Abstracts with Programs, v. 43, no. 5, p. 315.

Wolter, C.F., McKay, R.M., Liu, H., Bounk, M.J., and Libra, R.D., 2011 Geologic mapping for water quality projects in the Upper Iowa River watershed: Iowa Department of Natural Resources, Iowa Geological and Water Survey Technical Information Series, no. 54, $34 \mathrm{p}$.

Youngquist, W., and Cullison, J.S., 1946, The conodont fauna of the Ordovician Dutchtown Formation of Missouri: Journal of Paleontology, v. 20, p. 579-590.

Accepted 7 November 2016 